\title{
Effect of Sulfuric Acid Baking and Caustic Digestion on Enhancing the Recovery of Rare Earth Elements from a Refractory Ore
}

\author{
Rina Kim ${ }^{1, * \mathbb{D}}$, Heechan $\mathrm{Cho}^{2}$, Jinan Jeong ${ }^{2}$, Jihye Kim ${ }^{3}$, Sugyeong Lee ${ }^{4}$, Kyeong Woo Chung ${ }^{1}$, \\ Ho-Sung Yoon ${ }^{1}$ and Chul-Joo Kim ${ }^{1}$ \\ 1 Resources Recovery Research Center, Mineral Resources Division, Korea Institute of Geoscience and Mineral \\ Resources (KIGAM), Daejeon 34132, Korea; case7@kigam.re.kr (K.W.C.); hsyoon@kigam.re.kr (H.-S.Y.); \\ cjkim@kigam.re.kr (C.-J.K.) \\ 2 Department of Energy Resources Engineering, Seoul National University, Seoul 08826, Korea; \\ hccho@snu.ac.kr (H.C.); krenos@snu.ac.kr (J.J.) \\ 3 Department of Chemical Engineering and Applied Chemistry, University of Toronto, Toronto, ON M5S 3E5, \\ Canada; jhye.kim@mail.utoronto.ca \\ 4 Robert M. Buchan Department of Mining, Queen's University, Kingston, ON K7L 3N6, Canada; \\ sugyeong.lee@queensu.ca \\ * Correspondence: rkim@kigam.re.kr
}

Received: 28 April 2020; Accepted: 10 June 2020; Published: 12 June 2020

\begin{abstract}
To improve the recovery of rare earth elements (REEs) from a refractory ore, this study investigated two different chemical decomposition methods, namely sulfuric acid baking and caustic digestion, with their respective leaching processes. The studied lateritic ore contained goethite $(\mathrm{FeOOH})$ as a major constituent with REEs scattered around and forming submicron grains of phosphate minerals, such as apatite and monazite. Therefore, despite the substantially high content of REEs (3.4\% total rare earth oxide), the normal acidic leaching efficiency of REEs reached only $60-70 \%$. By introducing sulfuric acid baking and caustic digestion, the REE-leaching efficiency was significantly improved. After sulfuric acid baking at $2.0 \mathrm{acid} / \mathrm{solid}$ ratio and $200{ }^{\circ} \mathrm{C}$ for $2 \mathrm{~h}$, the leaching efficiency reached $97-100 \%$ in the subsequent water-leaching. When the ore was digested with a solid/liquid ratio of $100 \mathrm{~g} / \mathrm{L}$ in a $30 \mathrm{wt} \% \mathrm{NaOH}$ solution at $115^{\circ} \mathrm{C}$ and $300 \mathrm{rpm}$ for $3 \mathrm{~h}$, the REE-leaching efficiency of $99-100 \%$ was attained at $80^{\circ} \mathrm{C}$ using a $3.0 \mathrm{M} \mathrm{HCl}$ solution. The correlation between the REE and the Fe-leaching was determined. The improvements in REE-leaching in both methods were mostly attributed to the mineral phase and crystallinity changes of Fe-bearing minerals due to the ore pretreatments. Such findings were also supported by X-ray diffraction and scanning electron microscopy analyses.
\end{abstract}

Keywords: REE; sulfuric acid baking; caustic digestion; acid leaching; water leaching

\section{Introduction}

The rare earth elements (REEs) comprise 17 elements in the periodic table, namely the 15 lanthanide elements $(\mathrm{La}-\mathrm{Lu})$ plus $\mathrm{Sc}$ and $\mathrm{Y}$. These 17 elements are generally divided into two groups: $\mathrm{La}-\mathrm{Eu}$ (Nos. 57-63) are light REEs (LREEs), whereas Gd-Lu (Nos. 64-71) and Y (No. 39) are heavy REEs (HREEs). Sc is not classified in any of the two groups. The REEs are used in various high-tech industries, e.g., the manufacturing of computers, cell phones, optical glasses, phosphors, hybrid cars and batteries, because of their unique electrical and magnetic properties [1-4]. 
REEs can be recovered from different minerals. More than 250 rare earth minerals have been discovered to date [1], and the representative minerals are monazite $\left(\mathrm{REEPO}_{4}\right)$, bastnasite $\left(\mathrm{REECO}_{3} \mathrm{~F}\right)$ and xenotime $\left(\mathrm{YPO}_{4}\right)$. Monazite is an REE phosphate mineral that is very stable and difficult to leach under mild conditions. In contrast, bastnasite is an REE fluorocarbonate. When bastnasite is used as an REE resource, the fluorocarbonate should be converted first into an oxide or a sulfate to facilitate the succeeding leaching process. Xenotime is an yttrium phosphate mineral, which also has a very stable form; thus, similar to monazite, it is also difficult to leach under mild conditions. Other REE minerals include apatite, cheralite, eudialyte, loparite, phosphorite, secondary monazite and spent uranium solutions [4]. REEs are also found in ion-adsorbed clays; they are physically adsorbed onto the clays and are mostly HREEs [5-7].

Although there are several REE minerals in nature, only monazite, bastnasite and xenotime are commercially utilized [8]. General processing methods have been developed for these well-known REE minerals: acid baking (mostly by sulfuric acid) followed by water-leaching can be applied to treat them [8-13]. The REE phosphate minerals, i.e., monazite and xenotime, can also be effectively pretreated using a $\mathrm{NaOH}$ solution, and then, the converted REE hydroxide compounds are mostly leached in a weak acid solution $[8,12,14,15]$. Bastnasite can be leached by hydrochloric or sulfuric acid after a roasting process to decompose fluorine and carbonate [12]. The REEs from ion-adsorbed clays can be leached using an ammonium sulfate solution, the mechanism of which is similar to that of the ion exchange process [5-7].

However, the described methods are effective only when the minerals are recovered as high-grade concentrates and when the REE minerals exist as major minerals in the ores. Furthermore, the minerals contained within an ore vary depending on the mine; therefore, different processing methods need to be applied based on the ore type. Some researchers studied the leaching behavior of apatite containing considerable quantities of REEs. Habashi [16] reviewed the REE recovery from Kola apatite, and Jorjani et al. [17] conducted a leaching study using an apatite concentrate from the Chadormalu Plant in Iran. For the two studies, nitric acid was used as the leaching agent to prevent gypsum production. In addition, REEs in apatite can generally be recovered as a byproduct from calcium sulfate sludge from the wet processing of phosphoric acid [18,19]. REEs contained in apatite can also be treated by a two-step leaching method using hydrochloric acid as a leaching agent [20]. In the first step, approximately $80 \%$ of $\mathrm{Ca}$ and $60 \%$ of $\mathrm{P}$ are removed with almost no REEs loss, and the REEs are recovered at the second step with less impurities. Several metallurgical studies of refractory REE ores have also been conducted. In Brazil, Neumann and Medeiros [21] tried to separate the REE minerals from Araxá REE ore by physical methods; however, they decided to omit physical separation due to the complex mineralogy, fine REE crystals and particles having strong intergrowth with the gangue mineral. In a pilot plant, Araxá REE ore was introduced into direct leaching after sulfuric acid baking [15]. The REE ores in Chuktukon deposits from Russia showed similar mineralogical properties as the Araxá ores and direct chemical processing was also considered, i.e., nitric acid-leaching in an autoclave [22]. The processes mentioned above are summarized in Table 1.

As indicated in Table 1, appropriate processing methods based on the ore properties have to be developed to handle gangue minerals as well as REE minerals. This study investigated the enhancement in REE recovery from a refractory ore containing 3.4\% total rare earth oxide (TREO) by applying two different chemical decomposition methods followed by leaching processes, i.e., sulfuric acid baking-water-leaching and caustic digestion-acid-leaching. 
Table 1. Rare earth elements (REEs) recovery metallurgical processes.

\begin{tabular}{|c|c|c|c|c|}
\hline REE Mineral Type & Origin & Method & $\begin{array}{l}\text { REE-Leaching } \\
\text { Efficiency }\end{array}$ & Reference \\
\hline Monazite & Unknown & $\begin{array}{l}\mathrm{H}_{2} \mathrm{SO}_{4} \text { baking }\left(180-250^{\circ} \mathrm{C}\right) / \\
\text { Water-leaching }\left(70^{\circ} \mathrm{C}\right)\end{array}$ & $85-100 \%$ & Berry et al. [9] \\
\hline Monazite & Australia & $\begin{array}{l}\mathrm{H}_{2} \mathrm{SO}_{4} \text { baking }\left(250^{\circ} \mathrm{C}\right) / \\
\text { Acid-leaching }\left(0.9 \mathrm{M} \mathrm{H}_{2} \mathrm{SO}_{4},\right. \\
\left.20-25^{\circ} \mathrm{C}\right)\end{array}$ & $96 \%$ & Demol et al. [10] \\
\hline Red mud & Greece & $\begin{array}{l}\mathrm{H}_{2} \mathrm{SO}_{4} \text { baking }\left(700^{\circ} \mathrm{C}\right) / \\
\text { Water-leaching (room temperature) }\end{array}$ & $>80 \%(\mathrm{Sc} 60 \%)$ & Borra et al. [11] \\
\hline Apatite residue & Iran & $\begin{array}{l}\mathrm{H}_{2} \mathrm{SO}_{4} \text { baking }\left(270^{\circ} \mathrm{C}\right) / \\
\text { Water-leaching }\end{array}$ & $95 \%$ & Soltani et al. [13] \\
\hline $\begin{array}{l}\text { Bastnasite, } \\
\text { monazite }\end{array}$ & China & $\begin{array}{l}\text { Caustic digestion } \\
\left(\mathrm{NaOH}+\mathrm{Ca}(\mathrm{OH})_{2} \text { roasting, } 700^{\circ} \mathrm{C}\right) / \\
\text { Acid washing }(0.5 \mathrm{M} \mathrm{HCl}+0.05 \mathrm{M} \\
\left.\text { citric acid, } 400^{\circ} \mathrm{C}\right) / \\
\text { Acid-leaching }(3 \mathrm{M} \mathrm{HCl}+0.5 \mathrm{M} \\
\left.\mathrm{AlCl}_{3}, 70^{\circ} \mathrm{C}\right)\end{array}$ & $86 \%$ & Huang et al. [14] \\
\hline $\begin{array}{l}\text { Monazite, } \\
\text { xenotime, } \\
\text { bastnasite }\end{array}$ & Kyrgyz Republic & $\begin{array}{l}\text { Caustic digestion } \\
\left(\mathrm{Na}_{2} \mathrm{CO}_{3} \text { fusion)/Acid-leaching }\right. \\
\left(\mathrm{HNO}_{3}\right)\end{array}$ & - & $\begin{array}{l}\text { Buchanan et al. } \\
\text { [15] }\end{array}$ \\
\hline $\begin{array}{l}\text { Apatite, allanite, } \\
\text { chevkinite, titanite }\end{array}$ & Turkey & $\begin{array}{l}\text { Caustic digestion }\left(600^{\circ} \mathrm{C}\right) / \\
\text { Water-HCl-leaching }\end{array}$ & - & $\begin{array}{c}\text { Buchanan et al. } \\
\text { [15] }\end{array}$ \\
\hline Ion-adsorbed clays & Unknown & $\begin{array}{l}\text { Acidic-leaching }\left(0.5 \mathrm{M}\left(\mathrm{NH}_{4}\right)_{2} \mathrm{SO}_{4},\right. \\
\left.\mathrm{pH} 3 \text { by } \mathrm{H}_{2} \mathrm{SO}_{4}, 25^{\circ} \mathrm{C}\right)\end{array}$ & $80-90 \%$ & $\begin{array}{l}\text { Moldoveanu and } \\
\text { Papangelakis [7] }\end{array}$ \\
\hline Apatite & Iran & Acid-leaching $\left(60 \% \mathrm{HNO}_{3}, 60^{\circ} \mathrm{C}\right)$ & $59-74 \%$ & Jorjani et al. [17] \\
\hline Apatite & South Africa & $\begin{array}{l}\text { Acid-leaching }\left(1.0 \mathrm{M} \mathrm{HNO}_{3}, 0.5 \mathrm{M}\right. \\
\left.\mathrm{Ca}\left(\mathrm{NO}_{3}\right)_{2}\right)\end{array}$ & $85 \%$ & Preston et al. [18] \\
\hline Apatite & Mongolia & $\begin{array}{l}\text { Two-step acid-leaching } \\
\text { (1st: } 1.0 \mathrm{M} \mathrm{HCl} / 2 \mathrm{nd}: 2.0 \mathrm{M} \mathrm{HCl})\end{array}$ & $92-94 \%$ & Kim et al. [20] \\
\hline
\end{tabular}

\section{Materials and Methods}

\subsection{Ore Characteristics}

The ore used in this study was a lateritic ore containing goethite as a major mineral. Figure 1 shows an X-ray diffraction (XRD) analysis of the REE ore, where the goethite, ettringite, muscovite, maghemite, and apatite peaks can be observed. However, no REE mineral peaks appeared because their concentrations were much lower than those of Fe-bearing minerals, and the REEs were scattered throughout the ore. REE-containing particles were observed through a scanning electron microscopy (SEM) analysis, as displayed in Figure 2. In the subsequent energy-dispersive X-ray (EDX) analysis (Figure 3), Ce oxide and mixed REE grains were observed, and some REEs were likely to substitute Ca in the apatite lattice. In addition, considering the high intensity of REEs and $\mathrm{P}$ in the mixed REE particle presented in Figure 3c, the presence of an REE phosphate mineral, i.e., monazite, was also expected.

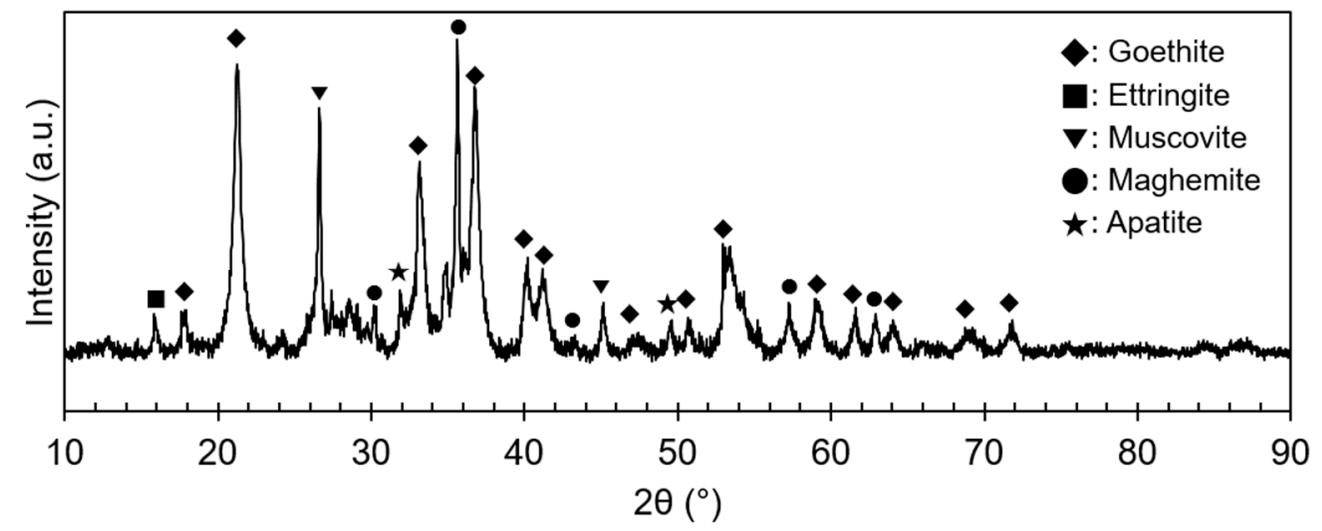

Figure 1. XRD pattern of the REE ore. 


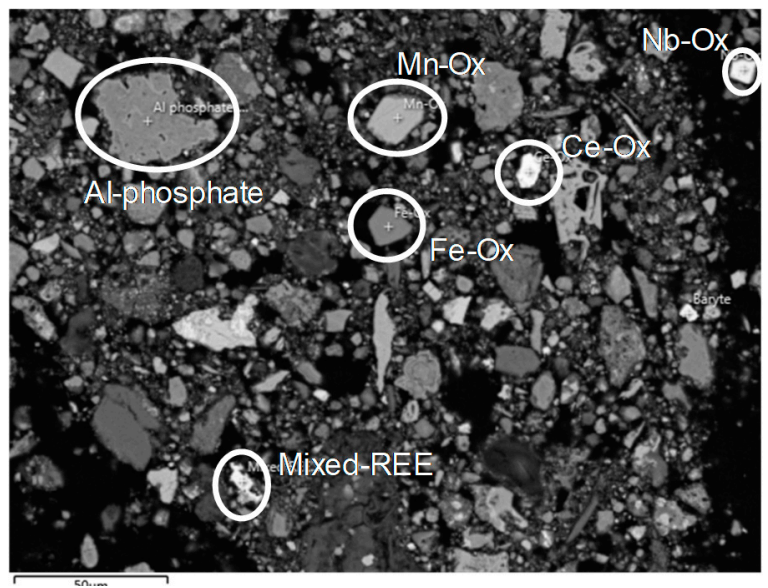

Figure 2. SEM image of the REE ore.

Because the ore was lateritic, the iron content was significantly high (more than $50 \%$ as $\mathrm{Fe}_{2} \mathrm{O}_{3}$ ) and $10 \%$ of manganese was present as an oxide as presented in Table 2. The TREO grade was 3.4\%, which is relatively high as an REE ore. Ce was the most abundant element, followed by La, $\mathrm{Nd}$ and $\mathrm{Y}$ (Table 2). The ore was obtained as a ground material, and the $80 \%$ passing size was $30 \mu \mathrm{m}$ (Figure 4 ).

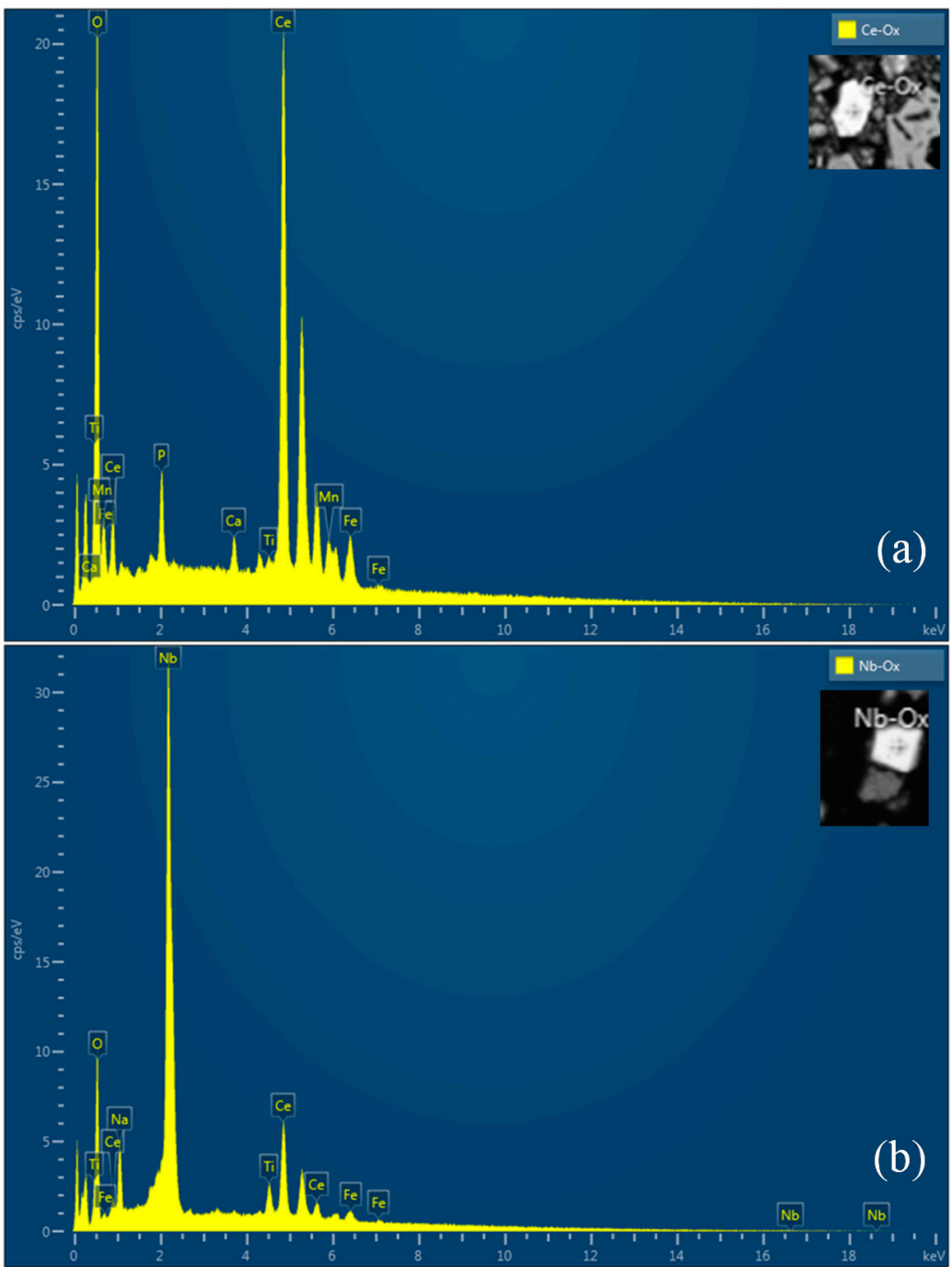

Figure 3. Cont. 


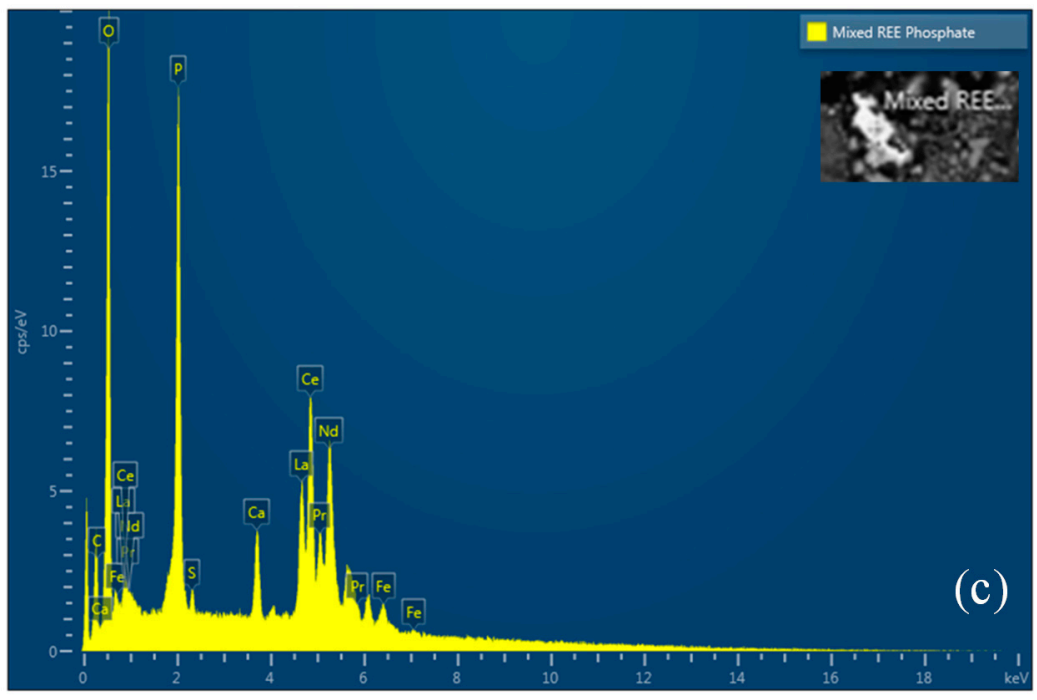

Figure 3. EDX spectra of REE-containing grains: (a) Ce oxide grain; (b) Nb oxide grain, which is host to minor $\mathrm{Ce}$; (c) mixed REE oxide grain with $\mathrm{Ca}$ and $\mathrm{P}$.

Table 2. Chemical composition of the REE ore.

\begin{tabular}{cccccccccccc}
\hline Formula & $\mathrm{Fe}_{2} \mathrm{O}_{3}$ & $\mathrm{MnO}$ & $\mathrm{SiO}_{2}$ & $\mathrm{P}_{2} \mathrm{O}_{5}$ & $\mathrm{Al}_{2} \mathrm{O}_{3}$ & $\mathrm{TiO}_{2}$ & $\mathrm{CaO}$ & $\mathrm{BaO}$ & $\mathrm{CeO}_{2}$ & $\mathrm{MgO}_{2}$ & $\mathrm{La}_{2} \mathrm{O}_{3}$ \\
\hline $\mathbf{w t} \%$ & 50.1 & 9.9 & 7.8 & 6.9 & 6.7 & 4.4 & 3.6 & 2.2 & 1.7 & 1.2 & 0.9 \\
\hline Formula & $\mathrm{K}_{2} \mathrm{O}$ & $\mathrm{SrO}$ & $\mathrm{Na}_{2} \mathrm{O}$ & $\mathrm{Nd}_{2} \mathrm{O}_{3}$ & $\mathrm{SO}_{3}$ & $\mathrm{Nb}_{2} \mathrm{O}_{5}$ & $\mathrm{ZnO}$ & $\mathrm{Cl}$ & $\mathrm{ZrO}_{2}$ & $\mathrm{Y}_{2} \mathrm{O}_{3}$ & $\mathrm{MoO}_{3}$ \\
\hline $\mathbf{w t} \%$ & 0.8 & 0.7 & 0.6 & 0.6 & 0.5 & 0.4 & 0.3 & 0.2 & 0.2 & 0.2 & 0.07 \\
\hline
\end{tabular}

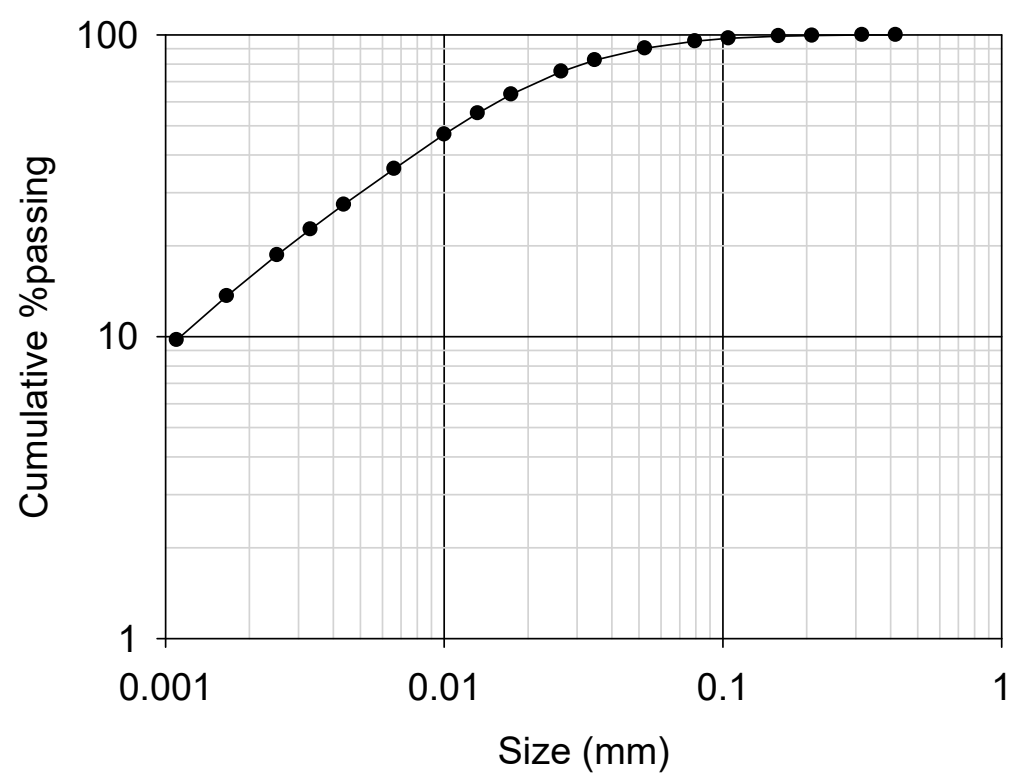

Figure 4. Cumulative particle size distribution of the ground REE ore $\left(\mathrm{P}_{80}\right.$ of $\left.30 \mu \mathrm{m}\right)$.

\subsection{Preliminary Leaching}

Generally, REE oxide can dissolve at a slightly acidic $\mathrm{pH}$ (pH of less than 4.0-5.0), and REE phosphate dissolves at a highly acidic $\mathrm{pH}$ of approximately $-1.0[20,23]$, respectively. The purpose of preliminary leaching was to determine if the REE minerals in the ore could really dissolve at those $\mathrm{pH}$ ranges. The suggested $\mathrm{pH}$ ranges can be achieved by hydrochloric or nitric acid concentrations of $2.0 \mathrm{M}$ or less. Using sulfuric acid for the preliminary tests was avoided because it can cause the REEs to co-precipitate with Ca minerals and interfere with the analysis of the REE-leaching behavior. 
In the preliminary leaching, 1.0-3.0 $\mathrm{M}$ of nitric acid was used as a leaching reagent as it has less effect on the REE-leaching behavior since nitrate anions rarely react with any metal cations. The leaching temperature was varied as 25,50 and $80^{\circ} \mathrm{C}$, with leaching times of $10 \mathrm{~h}, 3 \mathrm{~h}$ and $3 \mathrm{~h}$, respectively. All leaching tests were conducted with a pulp density of $10 \%(w / w)$. The leaching efficiency and final metal recovery were calculated as follows, respectively:

$$
\begin{gathered}
\text { Leaching efficiency }(\%)=\frac{C_{L} \times V}{M_{R} \times m_{R}+C_{L} \times V} \times 100 \\
\text { Final recovery }(\%)=\frac{C_{L} \times V}{M_{F} \times m_{F}} \times 100
\end{gathered}
$$

Here, $C_{L}$ is the metal concentration dissolved in the leaching solution $(\mathrm{mg} / \mathrm{L}), V$ is the volume of the leaching solution (L), $M_{R}$ and $M_{F}$ are the metal contents in the leaching residue and ore $(\mathrm{mg} / \mathrm{g})$, respectively, and $m_{R}$ and $m_{F}$ are the amounts of the leaching residue and the ore used in the leaching test $(\mathrm{g})$, respectively.

The leaching solution was sampled at regular intervals, and the samples were analyzed using inductively coupled plasma optical emission spectrometry (ICP-OES) to measure the metal concentration in the solution. The leaching residue and the ore were first fused by $\mathrm{NaOH}$, with an ore to $\mathrm{NaOH}$ ratio of $1: 10(w / w)$ at $400{ }^{\circ} \mathrm{C}$ for $1 \mathrm{~h}$. The fused products were then dissolved in aqua regia to measure the metal contents in the residue and the ore. They were also analyzed by ICP-OES. This solution analysis procedure was applied to all leaching tests in this study.

\subsection{Sulfuric Acid Baking-Water-Leaching}

To decompose the ore to a more soluble form, sulfuric acid baking was applied to the ore treatment. Various acid/solid ratios ( $w / w)$ were tested, i.e., $0.5,1.0$ and 2.0, and the ore and acid mixture was baked in a muffle furnace at $200{ }^{\circ} \mathrm{C}$ for $2 \mathrm{~h}$. The baked ore was subsequently introduced to the water-leaching step. Water-leaching was conducted at 25,50 and $80^{\circ} \mathrm{C}$ for $3 \mathrm{~h}$ with a pulp density of $10 \%(w / w)$.

\subsection{Caustic Digestion-Acid-Leaching}

For caustic digestion, sodium hydroxide was used as a caustic chemical, and $\mathrm{NaOH}$ solutions with concentrations of 20,30, 40 and 50\% (w/w) were prepared. For the caustic digestion step, the highest temperature without boiling was chosen for each $\mathrm{NaOH}$ solution concentration, i.e., $105^{\circ} \mathrm{C}$ at $20 \%, 115{ }^{\circ} \mathrm{C}$ at $30 \%, 120{ }^{\circ} \mathrm{C}$ at $40 \%$ and $145{ }^{\circ} \mathrm{C}$ at $50 \%$. The digestion was conducted for $3 \mathrm{~h}$, and the digested solid was then prepared for the subsequent acid-leaching reaction after solid/liquid separation and washing. The metal contents in the solid before and after digestion were measured by $\mathrm{X}$-ray fluorescence (XRF). The digested solid was leached by hydrochloric acid (1.0-3.0 M) at $80{ }^{\circ} \mathrm{C}$ and $10 \%$ $(w / w)$ pulp density for $3 \mathrm{~h}$.

\section{Results and Discussion}

\subsection{Preliminary Leaching Results}

As a baseline, ore-leaching tests in nitric acid solution at different $\mathrm{HNO}_{3}$ concentrations and temperatures were conducted. In the preliminary leaching, the leaching efficiency was equal to the final recovery as it was a single-step process.

Prior to the leaching tests, Eh- $\mathrm{pH}$ diagrams of REEs were considered. According to the Eh- $\mathrm{pH}$ diagrams (Figure 5), REE(III) hydroxide can simply dissolve in an acidic $\mathrm{pH}$ region. Cerium shows a slightly different characteristic because it can exist as two valence states, i.e., +3 and +4 . Ce(III) hydroxide behaves in a similar manner to other REE(III) hydroxides; however, if it oxidizes to a higher valence state, $\mathrm{Ce}(\mathrm{IV})$, its leaching can be inhibited under mild acidic conditions. The leaching behavior of $\mathrm{Ce}(\mathrm{IV})$ will be discussed thoroughly in later sections. 

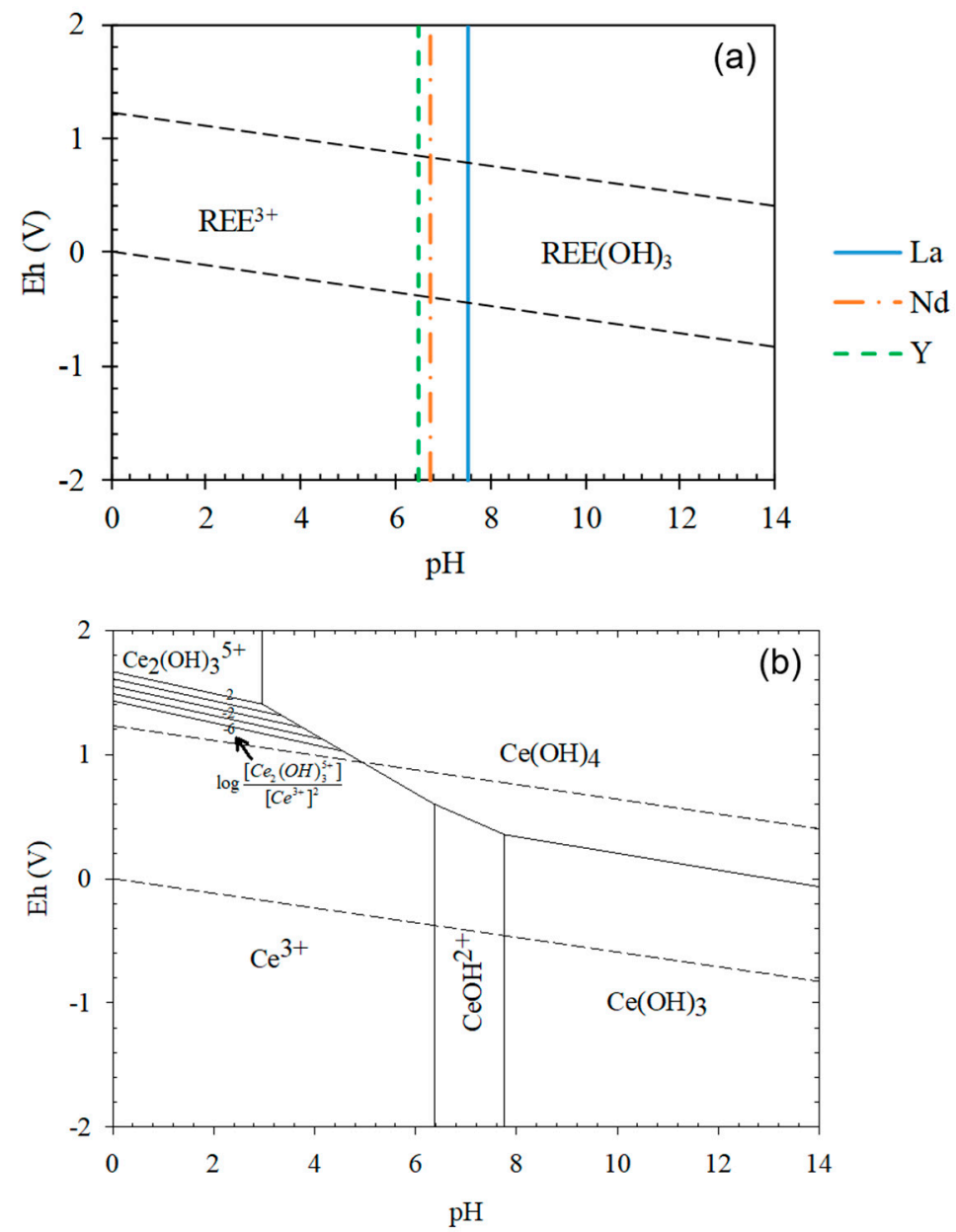

Figure 5. Eh-pH diagrams of REE systems: (a) (La, Nd and $\mathrm{Y})-\mathrm{OH}$; (b) $\mathrm{Ce}-\mathrm{OH}$ ([Ce], [La], [Nd], $[\mathrm{Y}]=0.01 \mathrm{M})$.

As depicted in Figure 6 and Table 3, the REE-leaching efficiency generally increased with increasing acid concentration from 1.0 to $2.0 \mathrm{M}$ at $25^{\circ} \mathrm{C}(\mathrm{Ce}=8.4-17.3 \%, \mathrm{La}=10.2-18.6 \%, \mathrm{Nd}=13.8-26.3 \%$ and $\mathrm{Y}=23.2-31.3 \%$ ) and temperature from 25 to $80{ }^{\circ} \mathrm{C}$ in $2.0 \mathrm{M} \mathrm{HNO}_{3}$ solution $(\mathrm{Ce}=17.3-43.6 \%$, $\mathrm{La}=18.6-49.9 \%, \mathrm{Nd}=26.3-57.3 \%$ and $\mathrm{Y}=31.3-48.2 \%)$. At $3.0 \mathrm{M} \mathrm{HNO}_{3}$ and $80{ }^{\circ} \mathrm{C}$, the REE recovery further improved to $63.0 \% \mathrm{Ce}, 61.4 \% \mathrm{La}, 72.3 \% \mathrm{Nd}$ and $55.9 \%$ Y. However, even though the REE-leaching efficiency was improved by the high acid concentration and temperature, the maximum efficiency only ranged from $61 \%$ to $73 \%$ and approximately $30-40 \%$ of the REEs remained in the solid phase.

The leaching levels of the major impurities, namely $\mathrm{Fe}, \mathrm{Ca}$ and $\mathrm{P}$, were also examined. The leaching levels of $\mathrm{Fe}$ and $\mathrm{P}$ were not significant because their maximum values were only $20.0 \%$ and $41.2 \%$, respectively, at $3.0 \mathrm{M} \mathrm{HNO}_{3}$ and $80^{\circ} \mathrm{C}$. However, the Ca-leaching level was as high as $94-100 \%$ even at the most moderate condition of $1.0 \mathrm{M} \mathrm{HNO}_{3}$ and $25^{\circ} \mathrm{C}$. Considering the mineralogy of the ore, Ca was mostly derived from apatite, and the $\mathrm{pH}$ of the solution was sufficiently low to dissolve apatite (less than 0.25 , Table 3), which is available at $\mathrm{pH}$ values between 1.0 and 3.3 [20]. The impurity-leaching behavior will be discussed in more detail in later sections related to the REE-leaching behavior.

In the succeeding residue analysis by SEM-EDX, some REE oxide particles or REE-containing grains were trapped in other mineral matrices (Figure 7). The size of REE grains was in the range between 1.5 and $12 \mu \mathrm{m}$, which suggests that further liberation was essential. However, the ore particle size was already very fine at $\mathrm{P}_{80}$ of $30 \mu \mathrm{m}$; therefore, the authors decided to conduct chemical decomposition methods to free the REE-containing grains from the trapping matrices and improve the leaching recovery. 


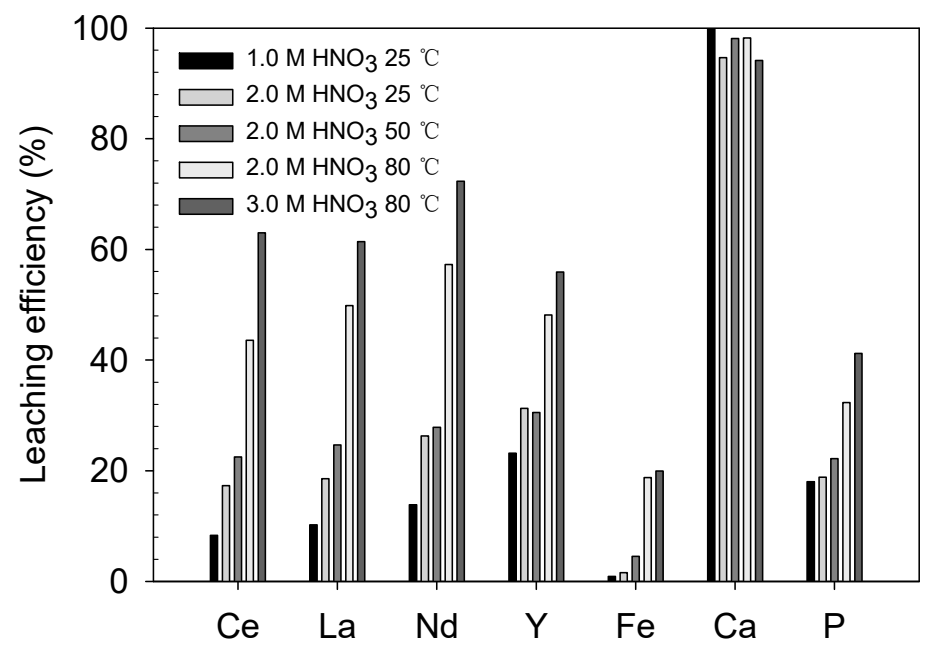

Figure 6. Preliminary leaching results: leaching efficiency (\%) of REEs and impurities at different $\mathrm{HNO}_{3}$ concentrations and temperatures.

Table 3. Preliminary leaching results: leaching efficiency (\%) of REEs and impurities at different $\mathrm{HNO}_{3}$ concentrations and temperatures.

\begin{tabular}{cccccccccc}
\hline \multirow{2}{*}{$\begin{array}{c}\mathbf{H N O}_{3} \\
\text { Concentration (M) }\end{array}$} & $\begin{array}{c}\text { Temperature } \\
\left({ }^{\circ} \mathbf{C}\right)\end{array}$ & Initial $\mathbf{~ p H}$ & \multicolumn{6}{c}{ Leaching Efficiency (\%) } \\
\cline { 4 - 10 } & & & $\mathbf{C e}$ & $\mathbf{L a}$ & $\mathbf{N d}$ & $\mathbf{Y}$ & $\mathbf{F e}$ & $\mathbf{C a}$ & $\mathbf{P}$ \\
\hline 1.0 & 25 & 0.25 & 8.4 & 10.2 & 13.8 & 23.2 & 0.9 & 100.0 & 18.0 \\
2.0 & 25 & -0.37 & 17.3 & 18.6 & 26.3 & 31.3 & 1.6 & 94.6 & 18.9 \\
2.0 & 50 & -0.24 & 22.5 & 24.7 & 27.8 & 30.5 & 4.5 & 98.1 & 22.2 \\
2.0 & 80 & -0.13 & 43.6 & 49.9 & 57.3 & 48.2 & 18.8 & 98.2 & 32.3 \\
3.0 & 80 & -0.36 & 63.0 & 61.4 & 72.3 & 55.9 & 19.9 & 94.1 & 41.2 \\
\hline
\end{tabular}
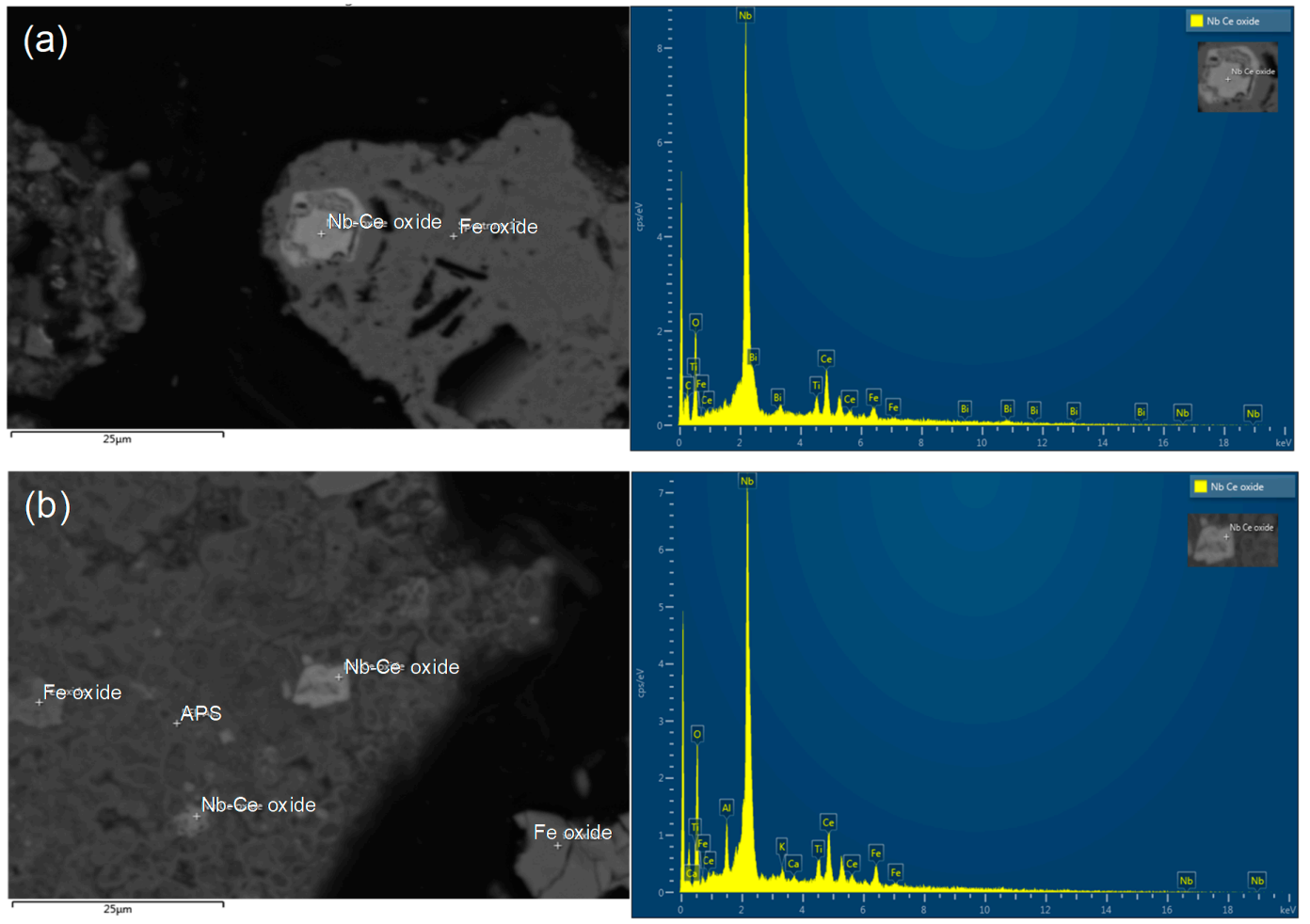

Figure 7. SEM-EDX analysis of preliminary leaching residue (leached at $3.0 \mathrm{M} \mathrm{HNO}_{3}$ and $80{ }^{\circ} \mathrm{C}$ ): (a) Fe oxide grain trapping $\mathrm{Nb}-\mathrm{Ce}$ oxide; (b) micro-breccia of alumino-phosphate-sulfate (APS) bearing Fe oxide and $\mathrm{Nb}-\mathrm{Ce}$ oxide. 


\subsection{Sulfuric Acid Baking-Water-Leaching}

\subsubsection{Effect of Acid/Solid Ratio}

Sulfuric acid baking was expected to decompose the minerals trapping the REEs and the REE phosphate mineral itself (monazite and REE-substituted apatite). Because the entire baking product was sent to the next water-leaching step, it was considered that the leaching efficiency was equal to the final recovery. The detailed recovery and mass balance data are provided in Table S1 of a Supplemental data.

Through the sulfuric acid baking, the expected chemical reactions are likely to be those indicated in Equations (3)-(5). The ore and acid mixture before and after baking are displayed in Figure 8. According to Equation (3) and other previous studies [11,24], FeOOH, an Fe(III)-containing mineral, can only convert to $\mathrm{Fe}(\mathrm{III})$ sulfate species during sulfuric acid baking. Similarly, in this study, it was confirmed that most of the $\mathrm{FeOOH}$ was converted to $\mathrm{Fe}_{2}\left(\mathrm{SO}_{4}\right)_{3}$ after the acid baking, regardless of the acid amount, at 1.0 and 2.0 acid/solid ratios (Figure 9). Although it was not detected from the XRD analysis, $\mathrm{Fe}(\mathrm{II})$ sulfate species seemed to be also formed, because the baked product color was pale green. This implied that a reductive reaction occurred during the baking process, but the mechanism was not clear. The authors assumed that it was the effect of unknown reductive materials in the ore and lack of oxygen sources in the closed muffle furnace.

$$
\begin{gathered}
2 \mathrm{FeOOH}+3 \mathrm{H}_{2} \mathrm{SO}_{4} \leftrightarrow \mathrm{Fe}_{2}\left(\mathrm{SO}_{4}\right)_{3}+4 \mathrm{H}_{2} \mathrm{O} \\
\mathrm{REEPO}_{4}+\mathrm{H}_{2} \mathrm{SO}_{4} \leftrightarrow \mathrm{REE}_{2}\left(\mathrm{SO}_{4}\right)_{3}+\mathrm{H}_{3} \mathrm{PO}_{4} \\
\mathrm{Ca}_{10}\left(\mathrm{PO}_{4}\right)_{6} \mathrm{X}_{2}+10 \mathrm{H}_{2} \mathrm{SO}_{4}=10 \mathrm{CaSO}_{4}+6 \mathrm{H}_{3} \mathrm{PO}_{4}+2 \mathrm{HX}(\mathrm{X}=\mathrm{OH}, \mathrm{Cl}, \mathrm{F})
\end{gathered}
$$

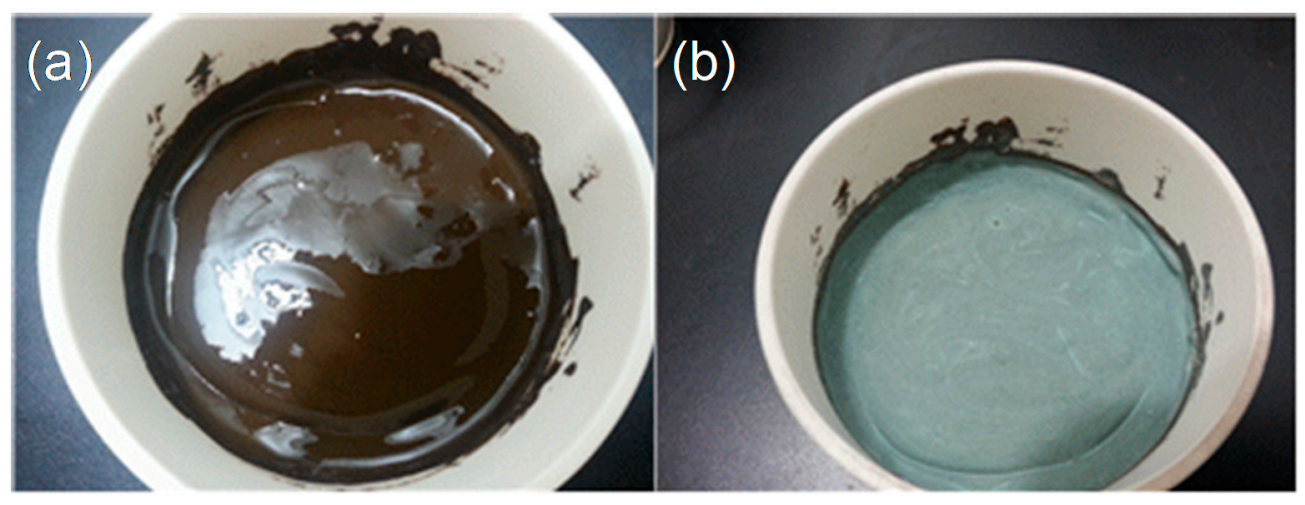

Figure 8. The ore and sulfuric acid mixture (a) before and (b) after baking at $200{ }^{\circ} \mathrm{C}$ for $2 \mathrm{~h}$.

In the succeeding water-leaching step, the REE recovery was significantly improved as shown in Figure 10, as the maximum levels were Ce $98.4 \%$, La $99.1 \%$, Nd100\% and Y $96.5 \%$ after baking at an acid/solid ratio of 2.0. The sulfuric acid concentration in the leaching step was calculated simply from the amount added for the baking step. The corresponding sulfuric acid concentrations in leaching solutions with acid/solid ratios of $0.5,1.0$ and 2.0 were $0.57,1.13$ and $2.27 \mathrm{M}$, respectively, although some part of the acid was consumed during the baking step. In the preliminary leaching results, when $0.5,1.0$ and $2.0 \mathrm{M}$ of nitric acid were used, the REE-leaching efficiency was significantly less than that of the baked sample. Thus, it can be concluded that the sulfuric acid baking effectively decomposed the minerals in the ore. 


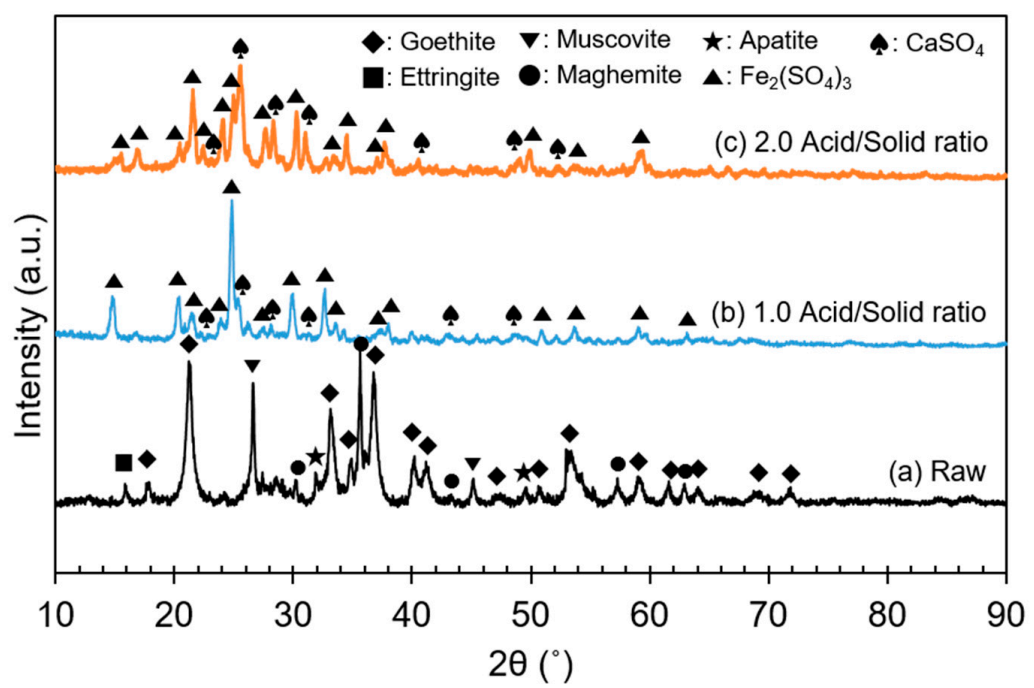

Figure 9. XRD patterns before and after sulfuric acid baking at different acid/solid ratios: (a) raw ore; (b) acid $/$ solid ratio $=1.0 ;(\mathbf{c})$ acid $/$ solid ratio $=2.0$.

In terms of impurity-leaching, the Fe and $\mathrm{P}$ recoveries were considerably increased to $38.0 \%$ and $30.3 \%, 65.9 \%$ and $60.6 \%$ and $81.1 \%$ and $87.5 \%$ after baking at $0.5,1.0$ and 2.0 acid/solid ratios, respectively, compared with the maximum $\mathrm{Fe}$ and $\mathrm{P}$ recoveries of $20.0 \%$ and $41.2 \%$, respectively, at $3.0 \mathrm{M}$ nitric acid and $80^{\circ} \mathrm{C}$. This also implied that the minerals were effectively decomposed via the acid baking process. In addition, the Fe recovery was much higher in this study than in the previous one [24], which was approximately $20 \%$ at $1.5 \mathrm{acid} /$ ore ratio. This was because the $\mathrm{Fe}(\mathrm{II})$ species formed in the current study were more soluble, whereas in the previous study, only less soluble Fe(III) species were present even after sulfuric acid baking.

In contrast, the $\mathrm{Ca}$ acted in a different manner from other metals. Its recovery remained at the same level of $57-58 \%$ regardless of the acid/solid ratio. This level was 1.62-1.65 times less than the recovery of the preliminary leaching results of $94.1 \%$ at $3.0 \mathrm{M}$ nitric acid and $80{ }^{\circ} \mathrm{C}$. Interestingly, the Ca recovery was considerably improved to $61.6,74.4$ and $97.7 \%$ after washing the leaching residues of $0.5,1.0$ and $2.0 \mathrm{acid} / \mathrm{solid}$ ratios, respectively. This is because calcium can easily form Ca-sulfate precipitates in a leaching solution in the presence of sulfate ions [20,25]; thus, the Ca recovery was not so high initially. After washing the residue with 3-4 times more water than the leaching solution amount, i.e., 300-400 mL, some of the Ca-sulfate precipitates were solubilized. More Ca dissolved at the higher acid/solid ratio because more residual acid remained in the solid residue pore. The precipitation problem will be further discussed in Section 3.2.2.
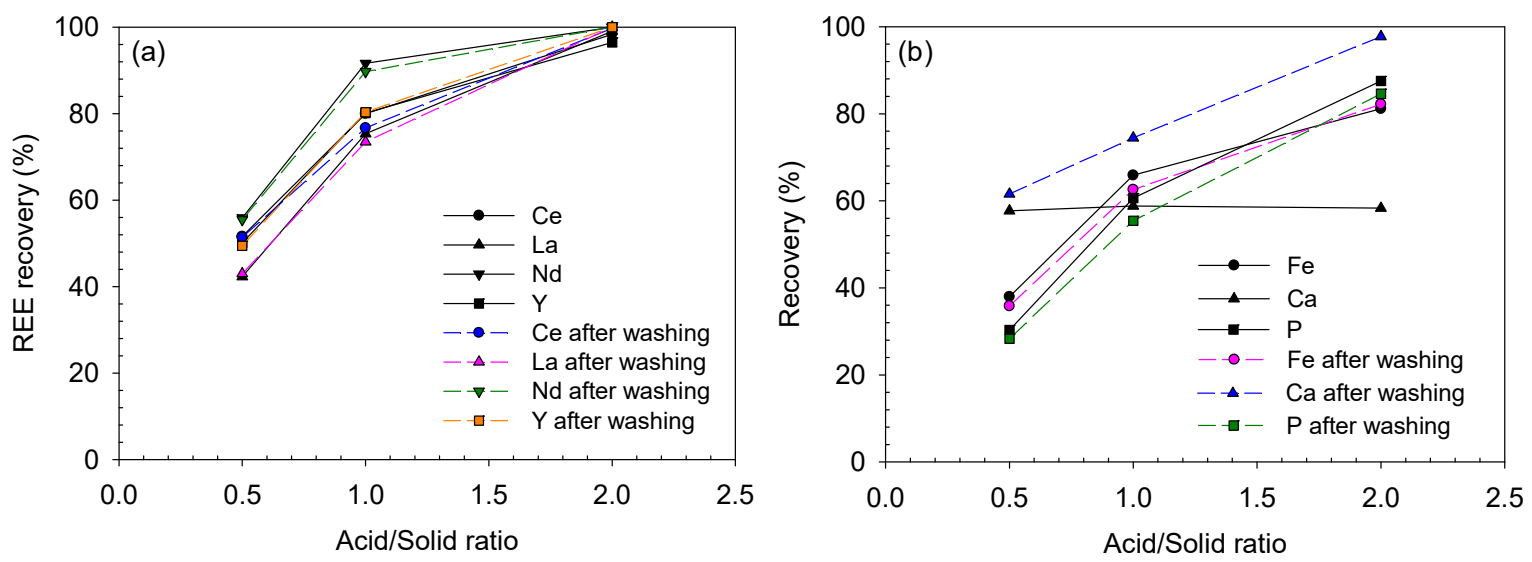

Figure 10. Leaching recoveries of (a) REEs and (b) impurities after water-leaching of the baked ore at different acid/solid ratios of sulfuric acid baking (baked at $200{ }^{\circ} \mathrm{C}$ for $2 \mathrm{~h}$ and leached at $25{ }^{\circ} \mathrm{C}$ for $3 \mathrm{~h}$ ). 


\subsubsection{Effect of Leaching Temperature}

The effect of temperature on the leaching process was examined for the ore treated with an acid/solid ratio of 2.0, which was the best condition for the highest recovery. As shown in Figure 11, the REE recovery decreased with increasing temperature from 25 to $80^{\circ} \mathrm{C}$. Between 25 and $50{ }^{\circ} \mathrm{C}$, only a slight decrease in recovery occurred, but the REE recovery significantly decreased to $60-72 \%$ at $80^{\circ} \mathrm{C}$, compared with $96-100 \%$ at $25^{\circ} \mathrm{C}$. This trend was also observed in the recovery of impurities: the $\mathrm{Fe}$, $\mathrm{Ca}$ and $\mathrm{P}$ recoveries decreased to $57.9,51.2 \%$ and $73.2 \%$ at $80{ }^{\circ} \mathrm{C}$, respectively, from $81.1,58.3 \%$ and $87.5 \%$ at $25^{\circ} \mathrm{C}$, respectively.

The decrease in recovery was because of Ca-sulfate precipitation. Calcium can easily form precipitates with sulfate ions owing to its low solubility as presented in Table 4 . The solubility of $\mathrm{Ca}$ sulfate, i.e., calcium sulfate dihydrate $\left(\mathrm{CaSO}_{4} \cdot 2 \mathrm{H}_{2} \mathrm{O}, \mathrm{CSD}\right.$ ), is only $2.68 \mathrm{~g} / \mathrm{L}$ at $25{ }^{\circ} \mathrm{C}$ (equivalent to $0.62 \mathrm{~g} / \mathrm{L} \mathrm{Ca})$; then, it increases between 25 and $40{ }^{\circ} \mathrm{C}$, and reduces to $2.59 \mathrm{~g} / \mathrm{L}(0.60 \mathrm{~g} / \mathrm{L} \mathrm{Ca})$ at $50{ }^{\circ} \mathrm{C}$ and $2.30 \mathrm{~g} / \mathrm{L}(0.54 \mathrm{~g} / \mathrm{L} \mathrm{Ca})$ at $80{ }^{\circ} \mathrm{C}[26,27]$. The REE sulfates also showed a decrease in solubility with increasing temperature, but their solubility concentrations were significantly higher than their concentrations in the leaching solution $(1.01 \mathrm{~g} / \mathrm{L} \mathrm{Ce}, 0.61 \mathrm{~g} / \mathrm{L} \mathrm{La}, 0.36 \mathrm{~g} / \mathrm{L} \mathrm{Nd}$ and $0.09 \mathrm{~g} / \mathrm{L} \mathrm{Y}$ at 2.0 acid/solid ratio and $25^{\circ} \mathrm{C}$ ). Despite these characteristics, the recoveries of REEs, Fe and P decreased at $80^{\circ} \mathrm{C}$. It seemed that these metals were adsorbed onto CSD and complexly reacted with each other to form co-precipitates. A similar behavior of REE co-precipitation and adsorption onto CSD was also observed in several previous studies $[20,25,28]$. They showed that the REE removal from the solution occurred at $\mathrm{pH}$ regions lower than the thermodynamic REE precipitation $\mathrm{pH}$; thus, the adsorption onto the CSD surface would be a major process.

Moreover, it is known that the solubility of REE phosphates also decreases with increasing temperature [29-31]; therefore, the REE phosphate precipitation also seemed to affect the recoveries of REEs and impurities. After leaching at $80^{\circ} \mathrm{C}$, the recoveries of REEs and impurities were significantly improved by the washing process because of the solubilization of the precipitated CSD, which contained the adsorbed metals.
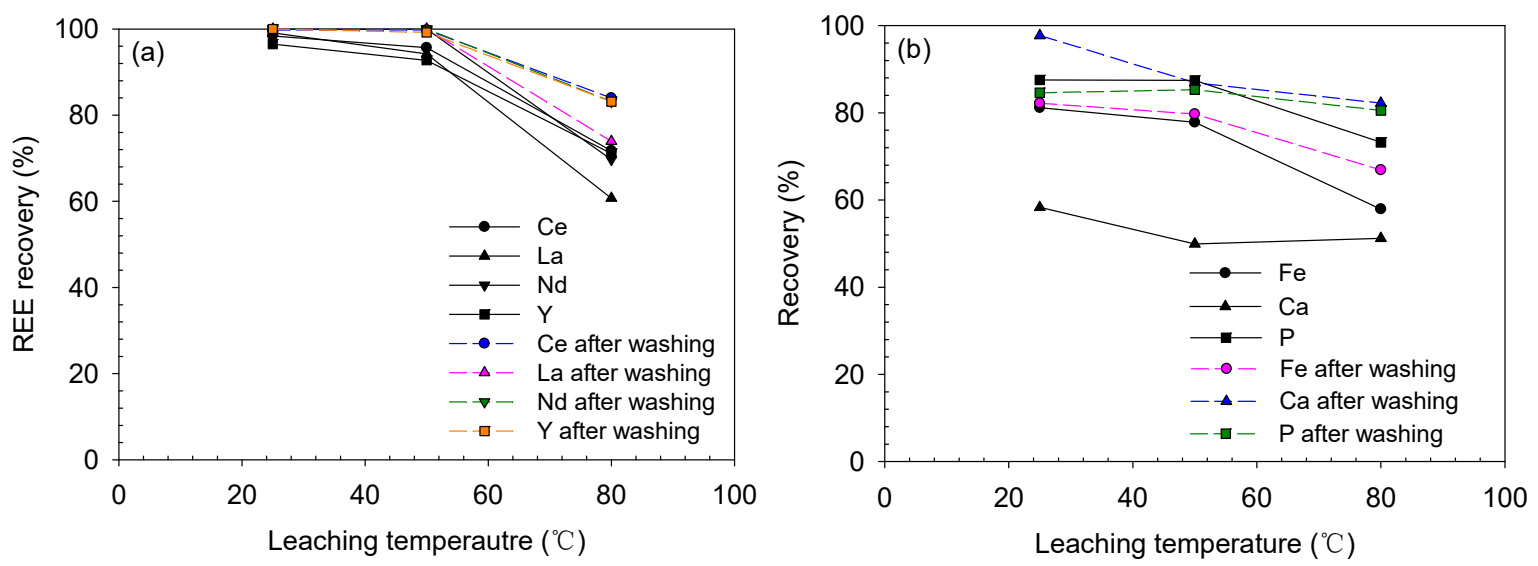

Figure 11. Leaching recoveries of (a) REEs and (b) impurities after water-leaching of the baked ore at $25-80{ }^{\circ} \mathrm{C}$ for $3 \mathrm{~h}$ (baked at $2.0 \mathrm{acid} /$ solid ratio and $200{ }^{\circ} \mathrm{C}$ for $2 \mathrm{~h}$ ). 
Table 4. Solubilities of Ca sulfate and REE sulfate compounds at 25,50 and $80^{\circ} \mathrm{C}$ (the numbers inside the parentheses are the solubility of Ca and REEs).

\begin{tabular}{cccc}
\hline \multirow{2}{*}{ Compound } & \multicolumn{3}{c}{ Solubility (g/L) } \\
\cline { 2 - 4 } & $\mathbf{2 5}{ }^{\circ} \mathbf{C}$ & $\mathbf{5 0}{ }^{\circ} \mathbf{C}$ & $\mathbf{8 0}{ }^{\circ} \mathbf{C}$ \\
\hline $\mathrm{CaSO}_{4} \cdot 2 \mathrm{H}_{2} \mathrm{O}^{1}$ & $2.68(0.62)$ & $2.59(0.60)$ & $2.30(0.54)$ \\
$\mathrm{Ce}_{2}\left(\mathrm{SO}_{4}\right)_{3}{ }^{2}$ & $85.2(42.0)$ & $46.9(23.1)$ & $32.2(15.9)$ \\
$\mathrm{La}_{2}\left(\mathrm{SO}_{4}\right)_{3}{ }^{2}$ & $20.9(10.3)$ & $14.7(7.22)$ & $9.53(4.68)$ \\
$\mathrm{Nd}_{2}\left(\mathrm{SO}_{4}\right)_{3}{ }^{2}$ & $48.3(24.2)$ & $28.8(14.4)$ & $19.7(9.87)$ \\
$\mathrm{Y}_{2}\left(\mathrm{SO}_{4}\right)_{3}{ }^{2}$ & $61.4(23.4)$ & $43.1(16.5)$ & $29.0(11.1)$ \\
\hline
\end{tabular}

${ }^{1}$ Dutrizac, 2002 [26]; ${ }^{2}$ Das et al., 2019 [32].

\subsection{Caustic Digestion-Acid-Leaching}

\subsubsection{Caustic Digestion Behavior}

The second decomposition method, i.e., caustic digestion, was conducted at different concentrations of $\mathrm{NaOH}$ solution, i.e., 20-50 wt \% . The significant chemical reactions of caustic digestion are shown in Equations (6)-(9).

$$
\begin{gathered}
\mathrm{REEPO}_{4}+3 \mathrm{NaOH} \leftrightarrow \mathrm{REE}(\mathrm{OH})_{3}+\mathrm{Na}_{3} \mathrm{PO}_{4} \\
\mathrm{Ca}_{10}\left(\mathrm{PO}_{4}\right)_{6} \mathrm{X}_{2}+20 \mathrm{NaOH} \leftrightarrow 10 \mathrm{Ca}(\mathrm{OH})_{2}+6 \mathrm{Na}_{3} \mathrm{PO}_{4}+2 \mathrm{NaX}(\mathrm{X}=\mathrm{Cl}, \mathrm{F}) \\
\mathrm{Ca}_{10}\left(\mathrm{PO}_{4}\right)_{6}(\mathrm{OH})_{2}+18 \mathrm{NaOH} \leftrightarrow 10 \mathrm{Ca}(\mathrm{OH})_{2}+6 \mathrm{Na}_{3} \mathrm{PO}_{4} \\
\mathrm{AlPO}_{4}+4 \mathrm{NaOH} \leftrightarrow \mathrm{Al}(\mathrm{OH})_{4}^{-}+4 \mathrm{Na}^{+}+\mathrm{PO}_{4}^{3-}
\end{gathered}
$$

It was expected that due to caustic digestion, the $\mathrm{Al}$ and $\mathrm{P}$ would be dissolved into the solution because they are very soluble in strong basic solutions, whereas the REEs would remain in the solid phase as a hydroxide. Actually, as the $\mathrm{NaOH}$ concentration was increased, the REEs were concentrated in the digested product, except $\mathrm{Y}$ ( $\mathrm{Y}$ is slightly amphoteric [33]), and the $\mathrm{Al}$ and $\mathrm{P}$ contents decreased in the solid phase and finally reached $1.0 \mathrm{wt} \%$ and $0.1 \mathrm{wt} \%$, respectively, in the $50 \mathrm{wt} \% \mathrm{NaOH}$ digested product (Figure 12). Iron is not soluble in basic solutions; thus, it was also concentrated in the digested product.
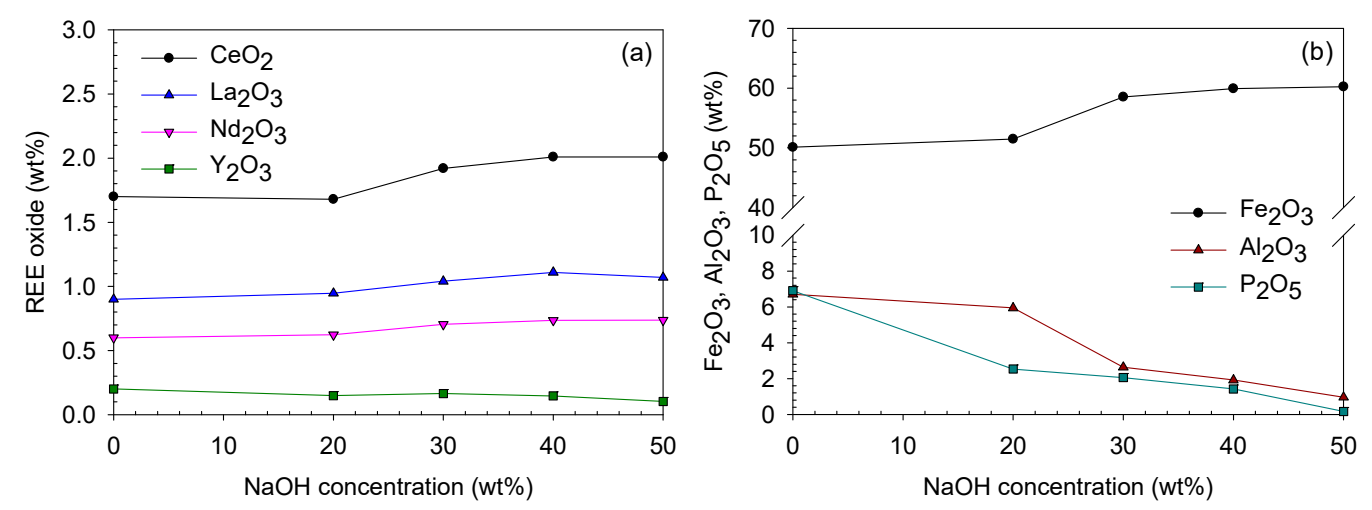

Figure 12. Oxide contents ( $w t \%$ ) of (a) REE and (b) Fe, Al and $\mathrm{P}$ of the digested product at different digesting $\mathrm{NaOH}$ concentrations.

Figure 13 shows that the intensity of goethite peaks in the digested product decreased. Representatively, at $2 \theta$ value of $21.3^{\circ}$, the peak intensity of goethite was 1019 and 363 before and after the digestion, respectively. Even some of the goethite peaks disappeared after digestion, although the Fe concentration increased. In contrast, the intensities of gangue mineral peaks, such as those of muscovite and ettringite, were relatively improved. These phenomena implied that the crystallinity of 
the goethite weakened, and it may be possible to free the trapped REE particles. Actually, as indicated in Figure 14, the surface of ore particles were chemically affected and eroded after caustic digestion.

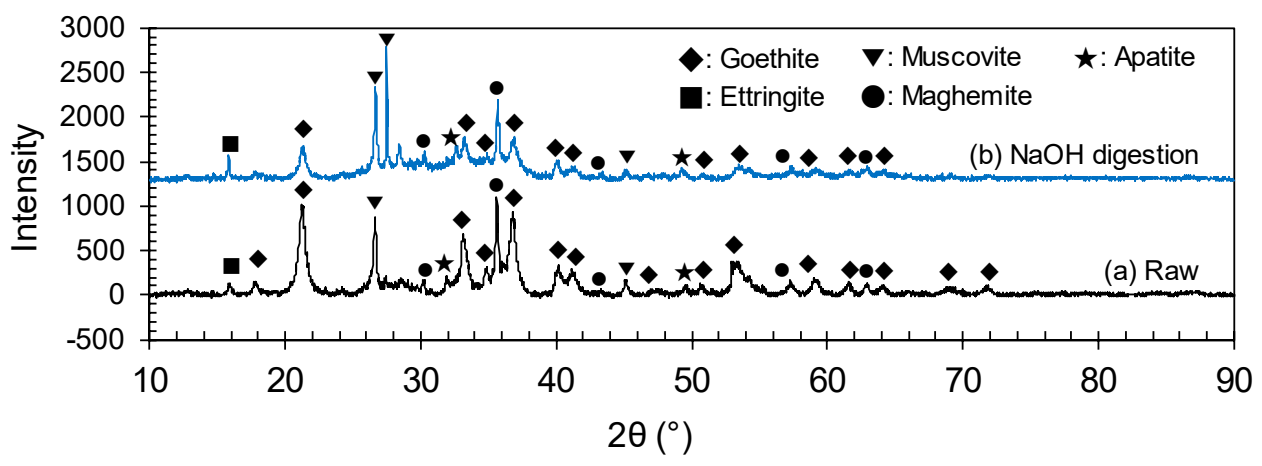

Figure 13. XRD patterns before and after caustic digestion using $50 \mathrm{wt} \% \mathrm{NaOH}$ solution.

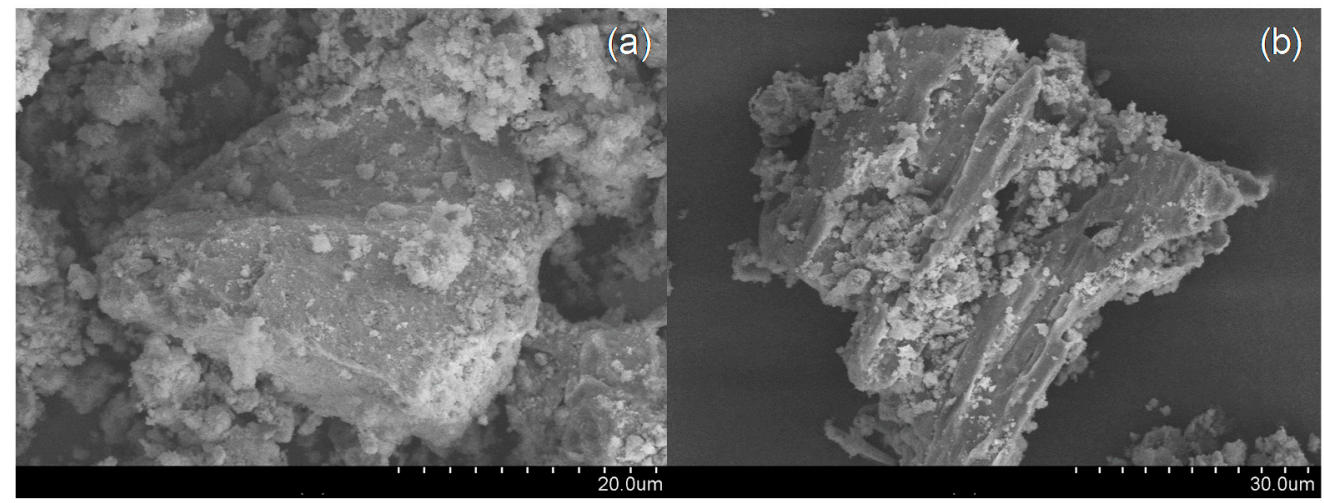

Figure 14. SEM images of the ore (a) before and (b) after caustic digestion (digestion condition: $50 \mathrm{wt} \%$ $\mathrm{NaOH}$ and $145^{\circ} \mathrm{C}$ for $3 \mathrm{~h}$ ).

\subsubsection{Acid-Leaching Behavior}

The caustic digested product was introduced to the succeeding acid-leaching step. During the digestion step, some elements of the ore were lost to the liquid phase, e.g., Al and P; thus, the leaching efficiency and final recovery were different in this test. The leaching efficiency was calculated based on the amount of elements in the digested product, whereas the recovery was based on the amount in the raw ore. The detailed recovery and mass balance data are provided in Table S2 of the Supplemental data.

The effect of acid concentration was initially investigated using 1.0-3.0 M hydrochloric acid. The digested ore was produced using a $50 \mathrm{wt} \% \mathrm{NaOH}$ solution. As presented in Figure 15, the REE-leaching efficiency generally increased as the acid concentration increased, while Ce behaved in a slightly different manner.

In the case of $\mathrm{Ce}$, its leaching efficiency only reached $12.1 \%$ at $1.0 \mathrm{M} \mathrm{HCl}$. It was improved at elevated $\mathrm{HCl}$ concentrations of 2.0 and $3.0 \mathrm{M}$ as $75.5 \%$ and $79.7 \%$, respectively; however, these values were still lower than those of other REEs at 2.0 and $3.0 \mathrm{M} \mathrm{HCl}$, which were in the range of $87-92 \%$ and 94-100\%, respectively. It seemed that some part of Ce was converted from Ce(III) to Ce(IV) compound during the digestion step, probably $\mathrm{Ce}(\mathrm{OH})_{4}$, which led to the low recovery of $\mathrm{Ce}$. $\mathrm{Ce}(\mathrm{OH})_{4}$ is less soluble than $\mathrm{Ce}(\mathrm{OH})_{3}$ as the solubility product of $\mathrm{Ce}(\mathrm{OH})_{4}$ is $10^{-51.56}$ and that of $\mathrm{Ce}(\mathrm{OH})_{3}$ is $10^{-26.15}$ [34]. This can be also confirmed from the Eh-pH diagram of the $\mathrm{Ce}-\mathrm{OH}$ system in Figure $5 ; \mathrm{Ce}(\mathrm{OH})_{3} \mathrm{can}$ simply be leached at a slightly acidic $\mathrm{pH}$, but $\mathrm{Ce}(\mathrm{OH})_{4}$ needs a highly acidic $\mathrm{pH}$. Although $\mathrm{Ce}(\mathrm{OH})_{4}$ was not detected from the XRD analysis due to its low concentration, it was probable that $\mathrm{Ce}(\mathrm{OH})_{4}$ was formed during the caustic digestion because of the significantly lower Ce-leaching efficiency than those of the other REEs. 
The final recoveries of $\mathrm{Ce}$, La and $\mathrm{Nd}$ showed almost similar trends with their leaching efficiencies. However, that of $\mathrm{Y}$ was significantly low, i.e., 26.2-38.4\% at 1.0-3.0 M HCl. This was because $\mathrm{Y}$ was dissolved and lost during the digestion step, and only $40 \%$ of $\mathrm{Y}$ from the raw ore was introduced into the acid-leaching step.

In terms of impurity-leaching, the Fe-leaching efficiency and recovery almost linearly increased as the acid concentration increased. The Al-leaching efficiency ranged from $95 \%$ to $100 \%$; hence, its final recovery was similar to that in the digestion step, which was in the range of $10-12 \%$. Phosphorus was not detected in any leaching solutions because it was removed during the digestion step.
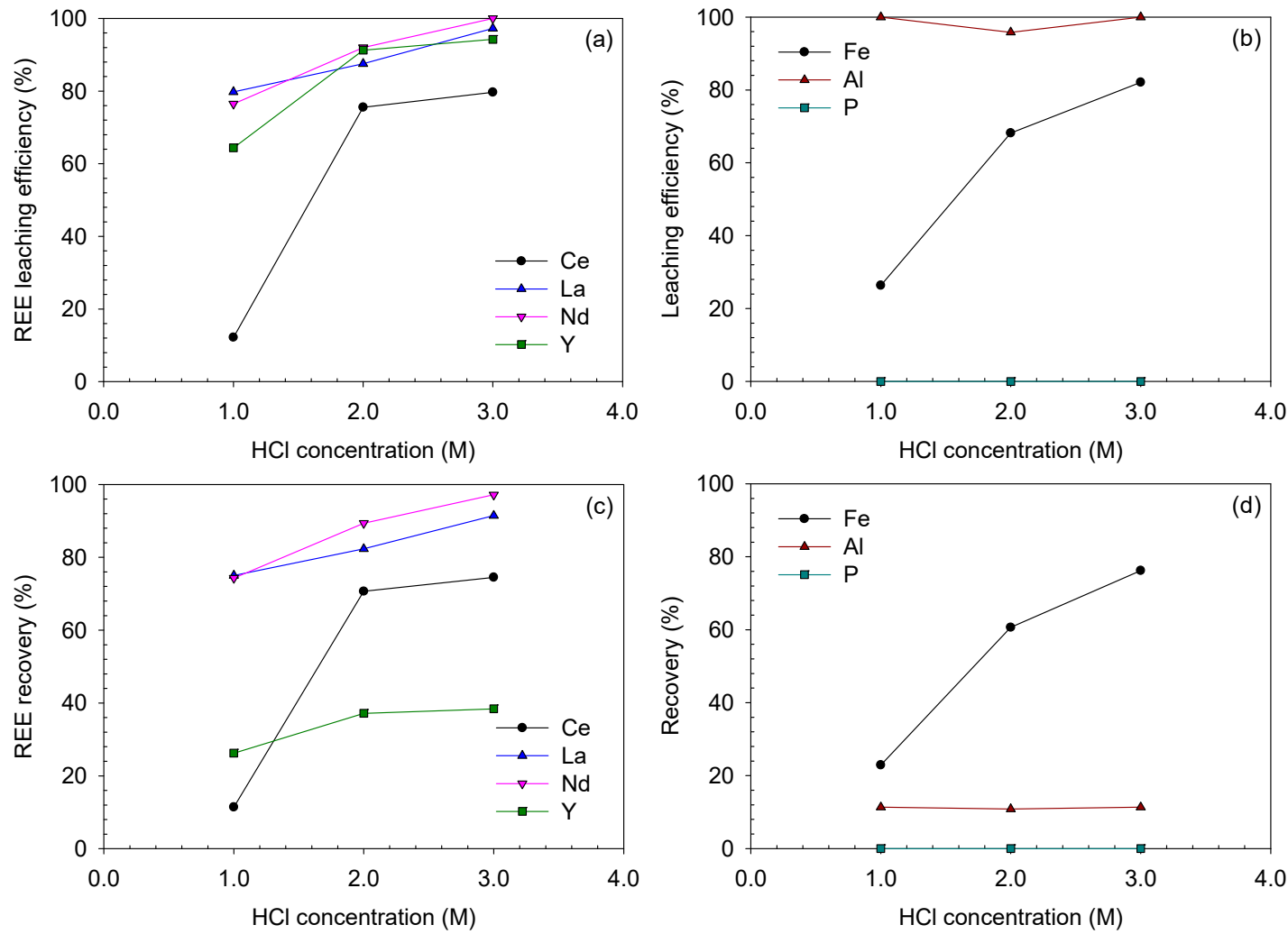

Figure 15. Leaching efficiencies and recoveries after acid-leaching of the caustic digested ore at $\mathrm{HCl}$ concentrations of $1.0-3.0 \mathrm{M}$ and $80^{\circ} \mathrm{C}$ for $3 \mathrm{~h}$ (digested using $50 \mathrm{wt} \% \mathrm{NaOH}$ solution for $3 \mathrm{~h}$ ): (a) REE and (b) Fe-, Al- and P-leaching efficiencies (\%); (c) REE and (d) $\mathrm{Fe}, \mathrm{Al}$ and $\mathrm{P}$ recoveries (\%).

Figure 16 illustrates variation of leaching results with the digesting $\mathrm{NaOH}$ concentration. In terms of leaching efficiency and recovery, both were maximized at $30 \mathrm{wt} \% \mathrm{NaOH}$ concentration, and those of $\mathrm{La}$ and $\mathrm{Nd}$ were not much changed at higher $\mathrm{NaOH}$ concentrations. However, Ce showed an evident decrease in the leaching efficiency and recovery at $\mathrm{NaOH}$ concentrations higher than $30 \mathrm{wt} \%$, which was caused by the less soluble $\mathrm{Ce}(\mathrm{OH})_{4}$ formation at higher $\mathrm{NaOH}$ concentrations. The final recovery of $\mathrm{Y}$ also significantly decreased as the $\mathrm{NaOH}$ concentration increased from $30 \mathrm{wt} \%$ to $50 \mathrm{wt} \%$, although the leaching efficiency remained high at 93-94\%. This was because its recovery from the digestion step decreased from $68 \%$ to $40 \%$ as the $\mathrm{NaOH}$ concentration increased from $30 \mathrm{wt} \%$ to $50 \mathrm{wt} \%$.

Concerning the impurities, the Fe-leaching efficiency had a similar trend to that of the REEs (except Ce), which increased between $20 \mathrm{wt} \%$ and $30 \mathrm{wt} \%$ in the range of $74-82 \%$. The Fe recovery was similar to its leaching efficiency, which ranged from $70 \%$ to $78 \%$. However, the $\mathrm{Al}$ and $\mathrm{P}$ recoveries considerably decreased from $64.2 \%$ to $11.3 \%$ and $27.0 \%$ to $0 \%$, respectively, as they were removed from the solution phase during the digestion step. In terms of leaching efficiency, that of P monotonously decreased, while that of $\mathrm{Al}$ fluctuated. It seemed that the residual $\mathrm{NaOH}$ in the digested product using $40 \mathrm{wt} \% \mathrm{NaOH}$ solution suppressed the Al-leaching. A small amount of $\mathrm{Al}$ remained in the digested 
product using $50 \mathrm{wt} \% \mathrm{NaOH}$ solution; thus, the Al-leaching efficiency reached $100 \%$, although a higher $\mathrm{NaOH}$ concentration was applied.
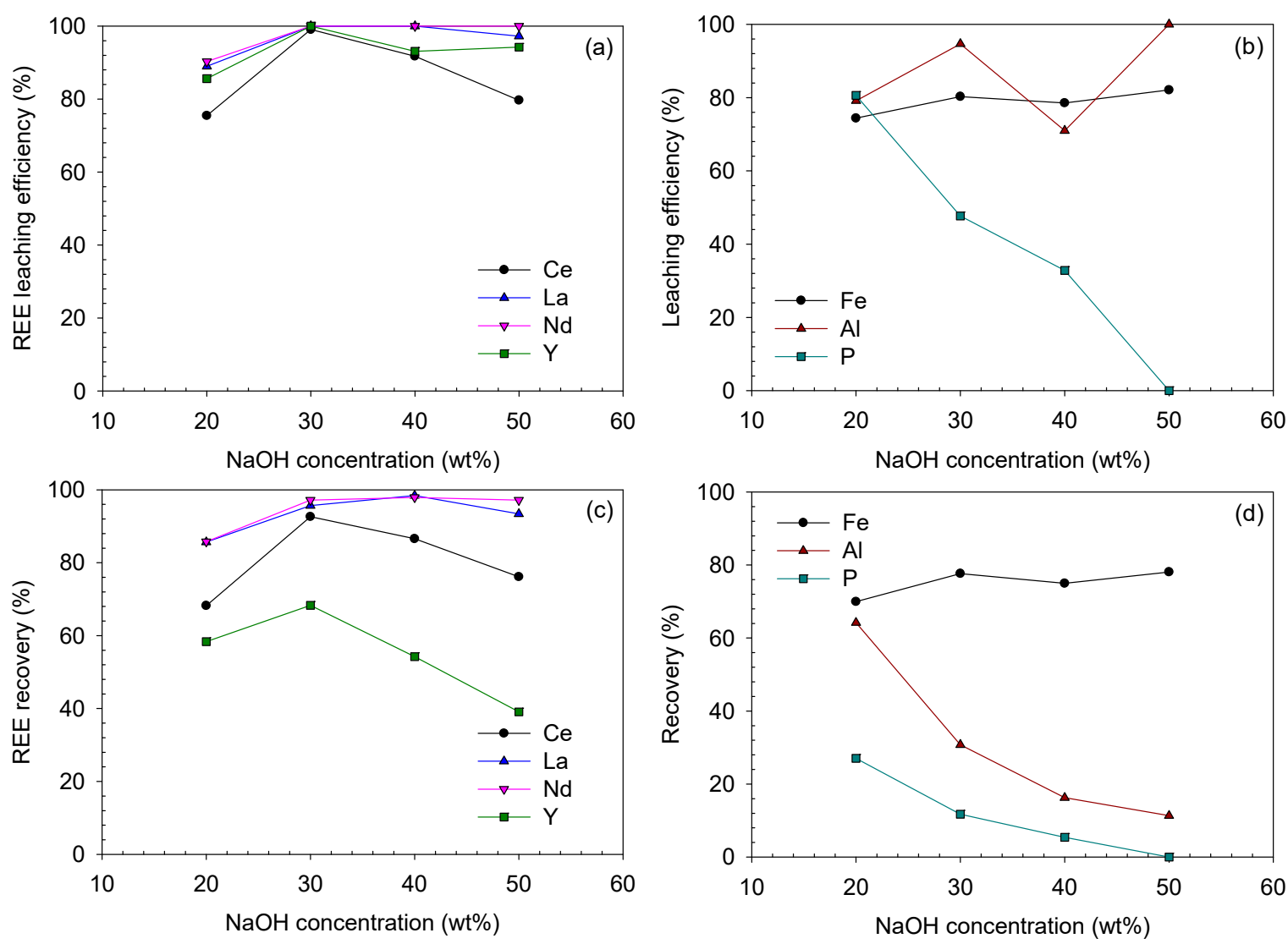

Figure 16. Leaching efficiencies and recoveries after acid-leaching of the caustic digested ore at digesting $\mathrm{NaOH}$ concentrations of $20-50 \mathrm{wt} \%$ (leached using $3.0 \mathrm{M} \mathrm{HCl}$ at $80^{\circ} \mathrm{C}$ for $3 \mathrm{~h}$ ): (a) REE and (b) Fe-, $\mathrm{Al}-$ and P-leaching efficiencies (\%); (c) REE and (d) $\mathrm{Fe}, \mathrm{Al}$ and $\mathrm{P}$ recoveries (\%).

\subsection{Determination of the Optimum Condition for Analyzing the REE-Fe-Leaching Efficiency Correlation}

To statistically analyze the REE-leaching behavior, correlation curves of the REE-Fe-leaching efficiency are plotted in Figures 17 and 18 and the calculated $\mathrm{R}^{2}$ values are listed in Table 5.

According to the analysis, the REE and Fe-leaching efficiencies were generally positively correlated. Specifically, the correlation was stronger during sulfuric acid baking-water-leaching (because the $\mathrm{R}^{2}$ values were much closer or even equal to 1.0000) than during caustic digestion-acid-leaching. This means that (i) REE-leaching highly depends on the Fe-bearing mineral decomposition, which traps the REE constituents during the sulfuric acid baking-water-leaching process and (ii) REEs and Fe co-precipitation by CSD affected a good $\mathrm{R}^{2}$ value; from REEs and Fe recovery trend before/after the residue washing process shown in Figures 10 and 11, their leaching behavior was somewhat governed by CSD formation as both the dissolved REEs and Fe can adsorb and desorb from CSD in a similar extent.

The curves showed a weaker REE-Fe correlation for the caustic digestion-acid-leaching test results, and the $\mathrm{Ce}-\mathrm{Fe}$ curve based on the $\mathrm{NaOH}$ concentration showed the weakest correlation with an $\mathrm{R}^{2}$ value of 0.1657 . This is because of the Ce oxidation to the $\mathrm{Ce}(\mathrm{IV})$ species of $\mathrm{Ce}(\mathrm{OH})_{4}$ as discussed earlier. In addition, the $\mathrm{La}$ and $\mathrm{Nd}$ leaching efficiencies showed weak correlations with that of $\mathrm{Fe}$ based on the digestion condition (Figure 18a) because they reached 100\% recovery at $80 \%$ Fe-leaching efficiency, which is slightly lower than the maximum Fe recovery of $82 \%$. If the points corresponding to the $50 \mathrm{wt} \% \mathrm{NaOH}$ digestion are removed, the REE-Fe correlations are improved: $0.9998 \mathrm{Ce}-\mathrm{Fe}, 0.9158$ $\mathrm{La}-\mathrm{Fe}, 0.9158 \mathrm{Nd}-\mathrm{Fe}$ and $0.9575 \mathrm{Y}-\mathrm{Fe}$. This implies that both the Fe-bearing mineral decomposition 
and digesting $\mathrm{NaOH}$ concentration can considerably affect the succeeding acid-leaching step in the caustic digestion-acid-leaching process. Based on the leaching condition, i.e., $\mathrm{HCl}$ concentration, the REE-Fe correlation was satisfactory regardless of the elements (Figure 18b).

Consequently, under the applied decomposition methods and leaching conditions in this study, the REE-leaching was more affected by Fe-leaching during sulfuric acid baking-water-leaching. At the Fe-leaching efficiencies of $68 \%$ and $66 \%$, the REE-leaching efficiencies (except Ce) were $88-92 \%$ and $75-80 \%$ from the caustic digestion-acid-leaching and sulfuric acid baking-water-leaching, respectively. Therefore, caustic digestion was a better decomposition method in terms of REE-leaching, and the REE-leaching was inhibited by CSD co-precipitation in the sulfuric acid baking-water-leaching process as the leaching efficiency was lower than in caustic digestion-acid-leaching at the same corresponding Fe-leaching level.

Overall, as the Fe-leaching reaches the maximum, the REE-leaching efficiency also attains its highest value; among the factors, the Fe-bearing mineral decomposition has the most significant effect on REE-leaching. Thus, considering the REE-leaching efficiency only, the optimum decomposition-leaching conditions are as follows: $2.0 \mathrm{acid} /$ solid ratio sulfuric acid baking $+25^{\circ} \mathrm{C}$ water-leaching for the sulfuric acid baking-water-leaching process and $30 \mathrm{wt} \% \mathrm{NaOH}$ digestion $+3.0-\mathrm{M} \mathrm{HCl}$-leaching at $80^{\circ} \mathrm{C}$ for the caustic digestion-acid-leaching.
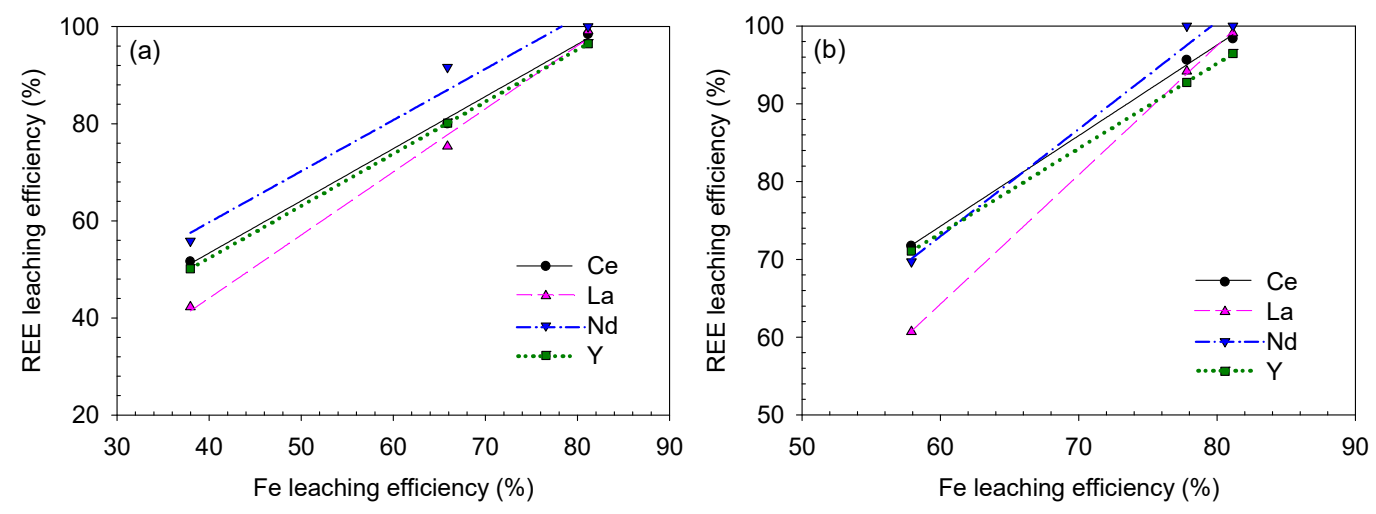

Figure 17. REE-Fe-leaching efficiency correlation for the sulfuric acid baking-water-leaching results based on (a) acid/solid ratio and (b) leaching temperature.
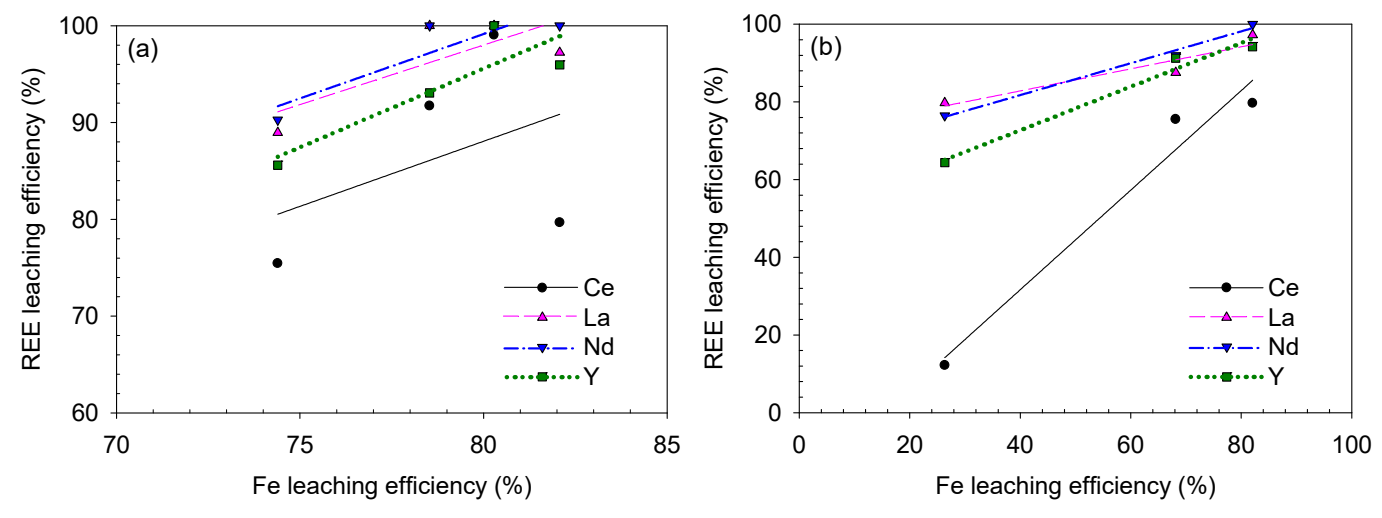

Figure 18. REE-Fe efficiency correlation for the caustic digestion-acid-leaching results based on (a) digesting $\mathrm{NaOH}$ solution concentration and (b) leaching $\mathrm{HCl}$ concentration. 
Table 5. $\mathrm{R}^{2}$ values of REE-Fe correlation curves based on the decomposition method and leaching condition.

\begin{tabular}{ccccc}
\hline \multirow{2}{*}{ Correlated Metals } & \multicolumn{2}{c}{ Sulfuric Acid Baking-Water-Leaching } & \multicolumn{2}{c}{ Caustic Digestion-Acid-Leaching } \\
\cline { 2 - 5 } & Acid/Solid Ratio & $\begin{array}{c}\text { Leaching } \\
\text { Temperature }\end{array}$ & $\begin{array}{c}\text { NaOH } \\
\text { Concentration }\end{array}$ & $\begin{array}{c}\text { HCl } \\
\text { Concentration }\end{array}$ \\
\hline $\mathrm{Ce}-\mathrm{Fe}$ & 0.9980 & 0.9984 & 0.1657 & 0.9652 \\
$\mathrm{La}-\mathrm{Fe}$ & 0.9946 & 0.9997 & 0.5990 & 0.8849 \\
$\mathrm{Nd}-\mathrm{Fe}$ & 0.9692 & 0.9824 & 0.8062 & 0.9899 \\
$\mathrm{Y}-\mathrm{Fe}$ & 1.0000 & 1.0000 & 0.7706 & 0.9772 \\
\hline
\end{tabular}

\section{Conclusions}

In this study, the effects of two different chemical decomposition methods, namely sulfuric acid baking and caustic digestion, to enhance the REE recovery from a refractory ore were investigated. The REE-containing particles were scattered throughout the ore, and some of them were even trapped in other minerals such as Fe oxide, although the total REE concentration was relatively high at $3.4 \%$ TREO. From the preliminary leaching tests using nitric acid, the maximum REE recovery only reached $61-73 \%$; thus, a significant amount of REEs was still left in the residue.

Using sulfuric acid baking-water-leaching, the REE recovery was improved to 97-100\% after the ore was baked at $2.0 \mathrm{acid} /$ solid ratio and $200{ }^{\circ} \mathrm{C}$ for $2 \mathrm{~h}$. The REE recovery reduced with increasing leaching temperature because of the CSD solid formation at elevated temperatures and the accompanying REE co-precipitation.

During the caustic digestion reaction, the REEs were concentrated in the solid phase as $\mathrm{Al}$ and $\mathrm{P}$ were removed to the solution phase by the decomposition reaction. In the succeeding acid-leaching, all REE-leaching efficiencies reached the maximum after $30 \mathrm{wt} \% \mathrm{NaOH}$ digestion for $3 \mathrm{~h}$ and $3.0 \mathrm{M}$ $\mathrm{HCl}$-leaching at $80^{\circ} \mathrm{C}$ for $3 \mathrm{~h}$. With increasing $\mathrm{NaOH}$ concentration, Ce became oxidized to $\mathrm{Ce}(\mathrm{IV})$ species of $\mathrm{Ce}(\mathrm{OH})_{4}$, and its leaching efficiency from the acid-leaching step decreased.

From the REE-Fe correlation analysis, a stronger correlation between the REEs and Fe was observed for the sulfuric acid baking-water-leaching results because of not only Fe-bearing mineral decomposition to iron sulfate, but also CSD precipitation with REEs and Fe. In addition, comparing the sulfuric acid baking-water-leaching and caustic digestion-acid-leaching, the caustic digestion showed a more powerful effect on enhancing the REE-leaching as it resulted to a higher REE-leaching efficiency at the same Fe-leaching level than that of sulfuric acid baking. It can be concluded that in terms of REE-leaching efficiency, as the Fe-leaching reached the maximum, the REE-leaching efficiency also attained its highest value. Furthermore, the Fe-bearing mineral decomposition significantly affected the REE-leaching of the studied ore.

Supplementary Materials: The following are available online at http://www.mdpi.com/2075-163X/10/6/532/s1, Table S1. Mass balance of sulfuric acid baking-water-leaching process; Table S2. Mass balance of caustic digestion-acid-leaching process.

Author Contributions: Conceptualization, R.K. and H.C.; methodology, R.K. and H.C.; validation, R.K., J.J., J.K. and S.L.; formal analysis, R.K., J.J., J.K. and S.L.; investigation, R.K.; resources, H.C., K.W.C., H.-S.Y. and C.-J.K.; data curation, R.K.; writing — original draft preparation, R.K.; writing-review and editing, H.C., K.W.C., H.-S.Y. and C.-J.K.; visualization, R.K.; supervision, H.C.; funding acquisition, H.C. and K.W.C. All authors have read and agreed to the published version of the manuscript.

Funding: This research was supported by the Energy Efficiency and Resources Core Technology Program of the Korea Institute of Energy Technology Evaluation and Planning (KETEP) granted financial resource from the Ministry of Trade, Industry and Energy (MOTIE) of the Korean government (No. 20122010300041). This research was also supported by the R\&D Center for Valuable Recycling (Global-Top R\&BD Program) of the Ministry of Environment of the Korean government (No. 2019002220001/KIGAM 20-9894).

Conflicts of Interest: The authors declare no conflicts of interest. 


\section{References}

1. Jordens, A.; Cheng, Y.P.; Waters, K.E. A review of the beneficiation of rare earth element bearing minerals. Miner. Eng. 2013, 41, 97-114. [CrossRef]

2. Massari, S.; Ruberti, M. Rare earth elements as critical raw materials: Focus on international markets and future stategies. Resour. Policy 2013, 38, 36-43. [CrossRef]

3. Golev, A.; Scott, M.; Erskine, P.D.; Ali, S.H.; Ballantyne, G.R. Rare earths supply chains: Current status, constraints and opportunities. Resour. Policy 2014, 41, 52-59. [CrossRef]

4. Xie, F.; Zhang, T.A.; Dreisinger, D.; Doyle, F. A critical review on solvent extraction of rare earths from aqueous solutions. Miner. Eng. 2014, 56, 10-28. [CrossRef]

5. Tian, J.; Chi, R.; Yin, J. Leaching process of rare earths from weathered crust elution-deposited rare earth ore. Trans. Nonferrous Met. Soc. China 2010, 20, 892-896. [CrossRef]

6. Chen, Z. Global rare earth resources and scenarios of future rare earth industry. J. Rare Earths 2011, 29, 1-6. [CrossRef]

7. Moldoveanu, G.A.; Papangelakis, V.G. Recovery of rare earth elements adsorbed on clay minerals: II. Leaching with ammonium sulfate. Hydrometallurgy 2013, 131-132, 158-166. [CrossRef]

8. Sadri, F.; Nazari, A.M.; Ghahreman, A. A review on the cracking, baking and leaching processes of rare earth element concentrates. J. Rare Earths 2017, 35, 739-752. [CrossRef]

9. Berry, L.; Agarwal, V.; Galvin, J.; Safarzadeh, M.S. Decomposition of monazite concentrate in sulphuric acid. Can. Metall. Quart. 2018, 57, 422-433. [CrossRef]

10. Demol, J.; Ho, E.; Senanayake, G. Sulfuric acid baking and leaching of rare earth elements, thorium and phosphate from a monazite concentrate: Effect of bake temperature from 200 to $800{ }^{\circ} \mathrm{C}$. Hydrometallurgy 2018, 179, 254-267. [CrossRef]

11. Borra, C.R.; Mermans, J.; Blanpain, B.; Pontikes, Y.; Binnemans, K.; Gerven, T.V. Selective recovery of rare earths from bauxite residue by combination of sulfation, roasting and leaching. Miner. Eng. 2016, 92, 151-159. [CrossRef]

12. Jha, M.K.; Kumari, A.; Panda, R.; Kumar, J.R.; Yoo, K.; Lee, J.Y. Review on hydrometallurgical recovery of rare earth metals. Hydrometallurgy 2016, 165, 2-26. [CrossRef]

13. Soltani, F.; Abdollahy, M.; Petersen, J.; Ram, R.; Javad Koleini, S.M.; Moradkhani, D. Leaching and recovery of phosphate and rare earth elements from an iron-rich fluorapatite concentrate: Part II: Selective leaching of calcium and phosphate and acid baking of the residue. Hydrometallurgy 2019, 184, 29-38. [CrossRef]

14. Huang, Y.; Dou, Z.; Zhang, T.; Liu, J. Leaching kinetics of rare earth elements and fluoride from mixed rare earth concentrate after roasting with calcium hydroxide and sodium hydroxide. Hydrometallurgy 2017, 173, 15-21. [CrossRef]

15. Buchanan, J.; Reveley, S.; Forrester, K.; Cummings, A. Review of current rare earth processing practice. In Proceedings of the ALTA 2014, Perth, Australia, 24-31 May 2014.

16. Habashi, F. The recovery of the lanthanides from phosphate rock. J. Chem. Technol. Biotechnol. Chem. Technol. 1985, 35, 5-14. [CrossRef]

17. Jorjani, E.; Bagherieh, A.H.; Chelgani, S.C. Rare Earth Elements Leaching from Chadormalu Apatite Concentrate: Laboratory Studies and Regression Predictions. Korean J. Chem. Eng. 2011, 28, 557-562. [CrossRef]

18. Preston, J.S.; Cole, P.M.; Craig, W.M.; Feather, A.M. the recovery of rare earth oxides from a phosphoric acid by-product. Part 1: Leaching of rare earth values and recovery of a mixed rare earth oxide by solvent extraction. Hydrometallurgy 1996, 41, 1-19. [CrossRef]

19. Wang, L.; Long, Z.; Huang, X.; Yu, Y.; Cui, D.; Zhang, G. Recovery of rare earths from wet-process phosphoric acid. Hydrometallurgy 2010, 101, 41-47. [CrossRef]

20. Kim, R.; Cho, H.; Han, K.N.; Kim, K.; Mun, M. Optimization of acid leaching of rare-earth elements from mongolian apatite-based ore. Minerals 2016, 6, 63. [CrossRef]

21. Neumann, R.; Medeiros, E.B. Comprehensive mineralogical and technological characterisation of the Araxá (SE Brazil) complex REE (Nb-P) ore, and the fate of its processing. Int. J. Miner. Process. 2015, 144, 1-10. [CrossRef]

22. Kuzmin, V.I.; Pashkov, G.L.; Lomaev, V.G.; Voskresenskaya, E.N.; Kuzmina, V.N. Combined approaches for comprehensive processing of rare earth metal ores. Hydrometallurgy 2012, 129-130, 1-6. [CrossRef] 
23. Kim, R.; Cho, H.; Han, K.N. Behavior of anions in association with metal ions under hydrometallurgical environments: Part I-OH- effect on various cations. Min. Metall. Explor. 2014, 31, 34-39. [CrossRef]

24. Guo, X.; Li, D.; Park, K.; Tian, Q.; Wu, Z. Leaching behavior of metals from a limonitic nickel laterite using a sulfation-roasting-leaching process. Hydrometallurgy 2009, 99, 144-150. [CrossRef]

25. Sadri, F.; Kim, R.; Yang, Z.; Ghahreman, A. The effect of calcium sulfate crystallization and the crystal modification on aqueous REE stability in Ca saturated REE-Ca-SO $\mathrm{S}_{4}-\mathrm{H}_{2} \mathrm{O}$ systems. Hydrometallurgy 2018, 182, 82-96. [CrossRef]

26. Dutrizac, J.E. Calcium sulphate solubilities in simulated zinc processing solutions. Hydrometallurgy 2002, 65, 109-135. [CrossRef]

27. Azimi, G.; Papangelakis, V.G.; Dutrizac, J.E. Modelling of calcium sulphate solubility in concentrated multi-component sulphate solutions. Fluid Phase Equilibr. 2007, 260, 300-315. [CrossRef]

28. Sadri, F.; Kim, R.; Ghahreman, A. Substitution of Calcium with Ce, Nd, Er, and Tb in the Structure of Microcrystals of Calcium Sulfates with Controlled Hydration Water: A Proposed Mechanism. Cryst. Growth Des. 2019, 19, 2621-2631. [CrossRef]

29. Firsching, F.H.; Brune, S.N. solubility products of the trivalent rare-earth phosphates. J. Chem. Eng. Data 1991, 36, 93-95. [CrossRef]

30. Poitrasson, F.; Oelkers, E.; Schott, J.; Montel, J. Experimental determination of synthetic $\mathrm{NdPO}_{4}$ monazite end-member solubility in water from $21^{\circ} \mathrm{C}$ to $300{ }^{\circ} \mathrm{C}$ : Implications for rare earth element mobility in crustal fluids. Geochim. Cosmochim. Acta 2004, 68, 2207-2221. [CrossRef]

31. Cetiner, Z.S.; Wood, S.A.; Gammons, C.H. The aqueous geochemistry of the rare earth elements. Part XIV. The solubility of rare earth element phosphates from 23 to $150^{\circ} \mathrm{C}$. Chem. Geol. 2005, 217, 147-169. [CrossRef]

32. Das, G.; Lencka, M.M.; Eslamimanesh, A.; Wang, P.; Anderko, A.; Riman, R.E.; Mavrotsky, A. Rare earth sulfates in aqueous systems: Thermodynamic modeling of binary and multicomponent systems over wide concentration and temperature ranges. J. Chem. Thermodyn. 2019, 131, 49-79. [CrossRef]

33. Ivano-Emie, B.N.; Nisel'son, L.A.; Ivolgina, A.T. Solubility of yttrium hydroxide in sodium hydroxide solution. Zhur. Neorg. Khim. 1961, 6, 1483-1484.

34. Joshi, S.; Kulp, E.A.; Fahrenholtz, W.G.; O'Keefe, M.J. Dissolution of cerium from cerium-based conversion coatings on $\mathrm{Al}$ 7075-T6 in $0.1 \mathrm{M} \mathrm{NaCl}$ solutions. Corros. Sci. 2012, 60, 290-295. [CrossRef]

(C) 2020 by the authors. Licensee MDPI, Basel, Switzerland. This article is an open access article distributed under the terms and conditions of the Creative Commons Attribution (CC BY) license (http://creativecommons.org/licenses/by/4.0/). 